\title{
Türk Tezyinatında Perde
}

\author{
Doç. Dr. Ela Taş \\ Sakarya Üniversitesi, Fen Edebiyat Fakültesi \\ Sanat Tarihi Bölümü \\ elatas@sakarya.edu.tr
}

\section{Öz}

Türk tarihinin erken devirlerinden itibaren ortaya konmuş her türlü eserin bitkisel motifler, geometrik şekiller, çeşitli hatlar, figürlerle tezyin edildiği günümüze ulaşan örneklerden anlaşılmaktadır. Bu süslemeler arasında yer alan ve nesnel motifler grubunda değerlendirilen unsurlardan biri perdedir. Perde ile ilgili kapsamlı bir çalışma yapılmamış olması, unsurun Batı etkisiyle Türk sanatında yer aldığına dair yanlış bir yaklaşımı da beraberinde getirmiştir. Bu çalışma, Batı sanatı vesilesiyle Türk tezyini sanatlarında kendine yer bulduğu söylenen perdenin; duvar resimleri, seramik, minyatür, resim ve mimari gibi unsurlar üzerinde bulunan örnekler eşliğinde, Hunlar döneminden itibaren Türk sanatında kullanım alanı bulduğunu ve kökeninin Orta Asya Türklerine dayandığını ortaya koymayı amaçlamaktadır.

Anahtar Kelimeler: Türk, Dekorasyon, Tezyinat, Perde.

\section{Curtains In Turkısh Decorative Art}

\begin{abstract}
It is obvious by the extant examples that every kind of artwork has been decorated by various motifs since the early periods of Turkish history. One of these decoration items which is evaluated among objective motifs is curtain. The fact that a detailed study has not been held on the mentioned motif accompanied a misconception that the motif ranks among Turkish art by the effect of the West. This study reveals that the curtain motif which is said to take place in Turkish decorative arts by the effect of Western art has indeed been used in Turkish art since the Huns era and originated by Middle Asia Turks to the accompaniment of examples on the elements such as frescos, ceramics, miniatures, drawings and architecture.
\end{abstract}

Keywords: Turkish, Decorative arts, Ornamentation, Curtain. 


\section{GİRIŞ}

Türkler, ortaya koydukları her türlü eseri nebati, hendesi, figürlü, hat, mimari şekiller, eşya ve manzaralı bezemeler başlıkları altında toplanan çeşitli unsurlar (Doğanay, 2012, s. 81-83) ile tezyin etmişlerdir. Bu gruplar dâhilinde yer alan rumi, hatayi, bulut, yazı gibi motifler ya da insan ve hayvan figürleri üzerine yazılmış detaylı pek çok çalışma mevcut olmakla birlikte, erken devirlerden itibaren Türk süslemeleri arasında yer alan bazı motiflere ise neredeyse değinilmemiş ya da Batı kaynaklı olduğu vurgusuyla yüzeysel olarak ele alınmıştır. Söz konusu durumdan payını alan unsurlardan biri perdedir. Perdenin batı kaynaklı bir motif olduğuna dair bilgilerin yer aldığı ilk çalışma "Batılılaşma Dönemi Türk Resim Sanatı 1700-1850" isimli kitaptır. Burada Silsilename adlı yazma eserde bulunan ve I. Selim'in tasvir edildiği minyatürde görülen perdenin, Avrupalı ressamların tablolarından esinlenilerek işlendiği belirtilmiştir (Renda, 1977, s. 35). Yine aynı yazar tarafından kaleme alınan "Osmanlı Minyatürü" isimli makalede, aynı minyatürden yola çıkılarak padişahların arkalarında gölgeli bir şekilde betimlenen perde motifinin, Avrupa resminden geldiği (Renda, 1997, s. 1270) vurgulanmıştır. Batı etkisiyle Türk tezyinatında yer bulduğuna dair bilgi içeren bir başka eserde "Batılılaşma Dönemi Anadolu Tasvir Sanatı" adlı kitaptır. Çalışmada çiçekli vazolar ve girlandların yanı sıra perdenin de batılı nitelikte motifler (Arık, 1988, s. 86) arasında olduğu belirtilmiştir. Bunların yanı sıra "18. ve 19. Yüzyıllarda Osmanlı Duvar Resimlerinde Betimleme Anlayışı" başlıklı yayımlanmamış doktora tezinde perdenin ikonografisine değinilmiş, ancak önceki çalışmalar dayanak gösterilerek motifin Batı kaynaklı olduğu ve duvar resimlerinden önce minyatürlerde işlendiği (Okçuoğlu, 2000, s. 49) bilgisine yer verilmiştir. Söz konusu eserler, ilerleyen süreçte geç dönem Osmanlı süslemelerinin ele alındığ 1 pek çok araştırmaya ${ }^{1}$ temel teşkil etmiş ve her birinde perdenin batı kaynaklı olduğu vurgusundan öteye geçilememiştir.

Perde ile ilgili detaylı bir çalışma yapılmaması, erken tarihlerde ortaya konmuş yazınlardaki bilgilerin devamlılığını sağlamış ve bunun sonucunda da motifin Batı etkisiyle Türk sanatında kullanım alanı bulduğu fikri kabul görmüştür.

Bu çalışma ile diş tesirlerle süsleme sanatlarımızda görülmeye başlandığı söylenen perdenin, erken devirlerden itibaren Türk tezyinatında yer aldığı ve kökeninin Orta Asya'ya dayandığı, çeşitli kaynaklarda tespit edilen görseller eşliğinde ortaya konmaya çalışılmıştır.

\footnotetext{
1 İsmail Aytaç-Elif Çeri Temel, "Kayseri (Germir) İbrahim Akdağ Evinde Duvar Resimleri”, Sanat ve İnsan Dergisi, S. 1(2), 2009, s. 4-12; Şerife Tali, “Giresun Yağlıdere Tekke Köyü Cami Kalem İşi Bezemeleri”, Uluslararası Sosyal Araştırmalar Dergisi, Cilt 7/31, 2014, s. 490-497; Gazanfer İltar, "Tekke Köyü Hacı Abdullah Halife Camisi Duvar Resimleri", Vakıflar Dergisi, S. 42, Ankara 2014, s. 69-80, Ela Taş, Klasik Devir Galerili Türbe Süslemeleri İçinde Sultan III. Mehmed Türbesinin Yeri, Ressjournal, S. 2, 2015, s. 739-754; Celil Arslan-Mehmet Pınar, "Nevşehir Cami ve Mescit Mihraplarında Bezeme Anlayışı", Erciyes Üniversitesi Sosyal Bilimler Enstitüsü Dergisi, S. 38, Kayseri 2015; Elif Gürsoy, "Uşak'ta Perde Motifli Mihraplar" ASOS JOURNAL Akademik Sosyal Araştırmalar Dergisi, S. 10, 2015, s. 146-157; Osman Ülkü, “Osmanlı Mimarisinde Manzara Resimleri Süslemeciliği Bağlamında Koçarlı-Cincin Köyü Cihanoğlu Hacı Abdülaziz Efendi Duvar Süslemelerinin Değerlendirilmesi, Sanat Tarihi Dergisi, Ege Üniversitesi Yayınları S. XXV/2, ̇̇zmir 2016, S. 277-293; Gökben Ayhan, "Birgi Karaoğlu Cami'nin Vaaz Kürsüsü, SDÜ Fen Edebiyat Fakültesi Sosyal Bilimler Dergisi, S. 39, Isparta 2016, s. 215-239; Eylem Yurdakul Tuğutlu, Kayseri Mihrapları, II. Baskı, Kayseri Belediyesi Yayınları, Kayseri 2019; Funda Naldan, "Geç Dönem Anadolu Kalemişi Süslemelerine Yeni Bir Örnek: Kemaliye Orta Cami”, Erdem, S. 76, Atatürk Kültür Merkezi Yayınları, Ankara 2019, s. 185-204 başlıklı makaleler perde motifinin batı kaynaklı olduğunu ve barok, rokoko, ampir tarzdaki yapılarda işlenen motifler arasında yer aldığına dair bilgiler içeren çalışmalardan bazılarıdır.
} 


\section{TÜRK TEZYINNATINDA PERDE}

Türkler, yerleşik yaşama geçişle birlikte iklim ve coğrafyaya göre şekillendirdikleri bark adı verilen kalıcı konutlar inşa etmişlerdir. Pencereli ya da penceresiz olarak tasarlanan bu yapılarda ortak bir cephe anlayışının olmaması Türklerin evin dışa yansıyan görüntüsüne çok önem vermediklerini göstermektedir (Ögel, 1978b, s. 65-69). D1ş taraftaki bu aldırmaz tutuma karşın yaşamlarını sürdürdükleri iç mekâna özen gösterdikleri günümüze ulaşan buluntulardan, belgelerden ve tasvirlerden anlaşılmaktadır. Ele geçen bulgular iç mekân tasarımında mefruşatın büyük önem taşıdığını göstermektedir. Bilindiği gibi mefruşat; yaşanılan mekânları döşemek amacıyla kullanılan halı, kilim, örtü, perde vb. şeyleri ifade etmektedir (Devellioğlu, 2010, s. 601). Bunlar soğuktan korunmak, mahremiyeti sağlamak ve iç mekâna estetik bir görüntü kazandırmak gibi amaçlarla kullanılmış döşeme unsurlarıdır.

Tarihsel süreçte evde sürdürülen hayatın gizliliği açısından kullanılan gereçler arasında ahşap pencere kapakları, mumlanmış bez ya da kâğıtları (Binan, 1997, s. 1443) ve perdeleri saymak mümkündür. İlk etapta türlü etkilerden korunmak amaciyla kullanılmaya başlanan bu unsurlardan perde, bir süre sonra dekorasyonun ayrılmaz bir parçası olmuştur.

Aslı Farsça olan perde; kapı, pencere gibi yerlere asılan örtü demektir. Estâr, icâh, sitr, sütûr gibi Arapça terimlerle özdeştir (Devellioğlu, 2010, ss. 1028, 269,467,1117, 1135). Orta Asya' da Türklere komşu olan Soğdakların yapılarında, çeşitli yerleri kapatmak için bu tür örtülerden istifade ettikleri ve bunları parde olarak isimlendirdikleri, Türklerin bu terimi onlardan aldıkları bunun yanı sıra "küşik, köşik" kelimelerini de perde yerine kullandıkları bilinmektedir (Ögel, 1978a, s. 240, 244).

Perde yalnızca pencereleri örtmek için kullanılmamış aynı zamanda gölgelik (çetr) olarak, iç mekânda bölmeler oluşturmak, yatakta yatan kişinin görünmesini önlemek ve bina cephelerine hareketlilik kazandırmak gibi amaçlara da hizmet etmiştir (Ögel, 1978a, s. 241, 244).

Orhun-Selenga bölgesinde MÖ. IV-II. yüzyıllar arasında varlık gösteren Hunların, ahşap direkler ve kamış kullanarak, kafes örgü tekniğinde duvarlara sahip köşkler yaptıkları ve bunlara kumaştan yapılan perdeler astıkları araştırmalarla ortaya konmuştur (Esin, 2006, s. 130). MÖ. II. yüzyılda Asya Hunlarına bağlı Kırgızların (Taşağıl, 2012, s. 471) curt, bozüy isimleriyle de bilinen daire biçimli, koni formunda kubbeyle örtülü, keçe kaplamalı (Özünlü, 2014, s.172) yurt tipi çadırların yanı sıra ordugâh olarak kurulan yerleşimlerde köşkler de inşa edilerek ikamet amaçlı kullanılmıştır. Bunlardan biri olan Abakan şehri köşklerinin; içte dar, dışta geniş pencerelere sahip olduğu ve bunların tahtaların örülmesiyle oluşturulan kafeslerle ya da kumaşlarla örtüldügü bilinmektedir (Esin, 2006, s. 50).

Göktürk döneminde, Çin kültürünün etkisiyle inşa edilen köşklerde perde kullanıldığı günümüze ulaşan mezar taşlarında yer alan bazı ifadelerden anlaşılmaktadır. Bunun yanı sıra bir Çinli şairin de Türk çadırlarının her yanının yumuşak örtülerle döşeli olduğunu ve içlerinde salep renginde perdeler bulunduğunu bildirmesi, bunun yanı sıra Çin edebiyatında gök rengindeki otağın içinde keçe örtülere ve perdelere yer verildiğinin belirtilmesi de (Esin, 2006, s. 62, 128) Türkler için mefruşatın en önemlisi de perdenin seçkin bir yerinin olduğunu göstermesi açısından dikkat çekicidir.

Yaşam alanında çeşitli amaçlarla değerlendirilen perdenin, yazılı belgeler ve görseller çerçevesinde Türkler tarafından erken devirlerden beri kullanıldığı anlaşılmaktadır. $\mathrm{Bu}$ 
tasarrufun sadece maddi boyutta kalmadığı, başlı başına bir motif olarak duvar resimlerinde, taş işçiliği, seramik, minyatür, resim gibi çeşitli alanlarda da süsleme amacıyla değerlendirildiği görülmektedir.

Türklerde perdenin tezyianatta kullanıldığını gösteren ilk tasvirler, 745 yılında Ötüken merkezli olarak kurulan Uygur dönemine (Çoruhlu, 2013, s. 247) ait yazmalarda ve duvar resimlerinde karşımıza çıkmaktadır. Bu yazmalarda; Budizm'i benimsemiş Uygur Türklerinin Doğu Türkistan'da göl ve nehir kenarlarında, korular içerisinde çeşitli yalı külliyeleri oluşturdukları, yapıların cephelerini aşı boyası ve yaldızla renklendirdikleri, çeperlerini pencerelerle donattıkları ve bunların tıpkı Kırgızlar dönemindeki gibi hasır örtüler (Görsel 1,2) ya da perdelerle süsledikleri yer almaktadır. Arkeolojik çalışmalar sonucunda ortaya çıkarılan bulgular, bu bilgileri doğrulamaktadır (Esin, 1975, s. 3,4; Esin, 2006, s. 71).

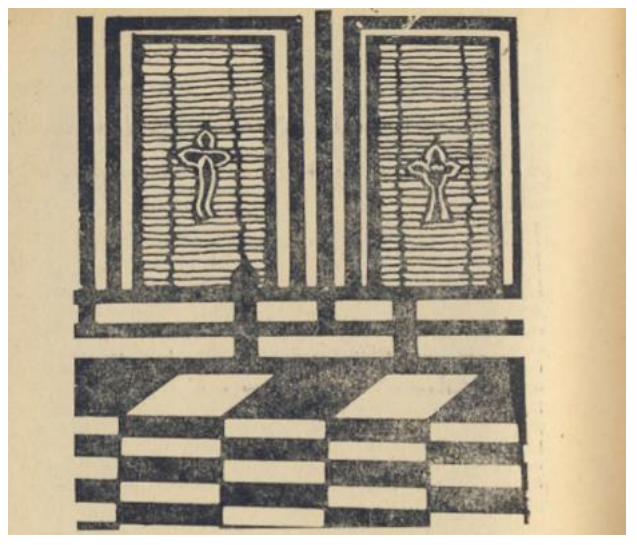

Görsel 1. Uygur Çağı Penceresi

(B. Ögel)

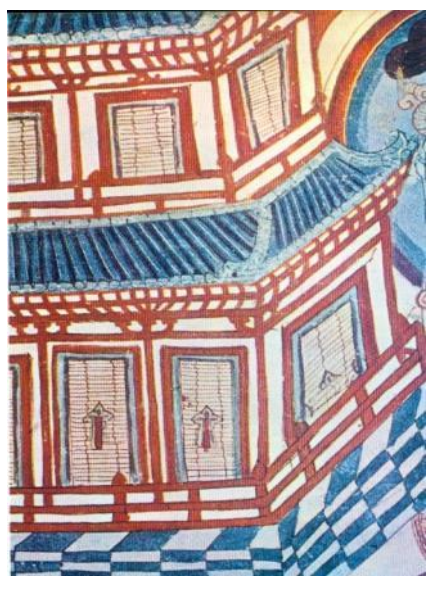

Görsel 2. Uygur Devri Köşkü

(E. Esin)

Yine bu süreçte perdenin, mimariyi tamamlamak ve ona estetik bir görüntü kazandırmak amacıyla yapıların cephelerine (Görsel 3) ve iç mekânlarına asılarak kullanıldığı bilinmektedir. Özellikle taht köşklerinin, salonlarının ve tahtın arkasındaki duvarın gösterişli kılınmak istenmesi buraların perdelerle taçlandırılarak dekore edilmelerini beraberinde getirmiştir. Bu uygulama ile ortamın ihtişamının arttırıldığı, döneme ait duvar resimlerinden anlaşılmaktadır (Görsel 4-5).

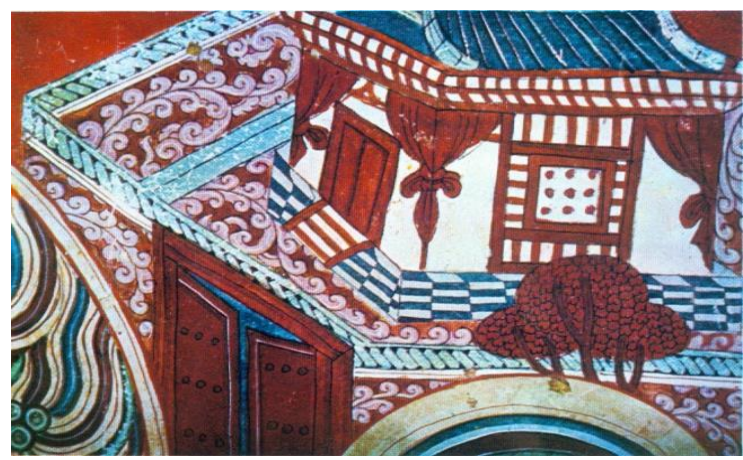

Görsel 3. Perdeyle süslenmiş Uygur Köşkü (E. Esin) 


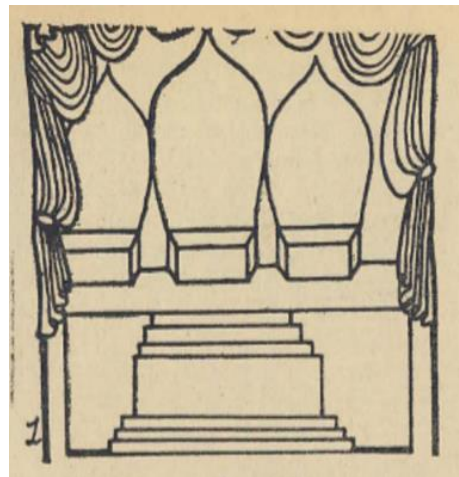

Görsel 4. Perdeyle taçlandırılmış

taht salonu (B. Ögel)

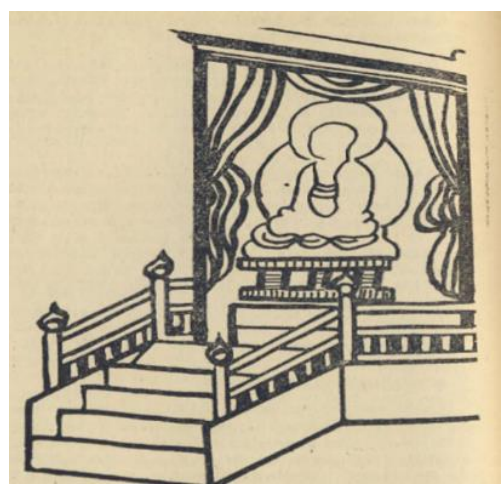

Görsel 5. Perde ile çevrelenmiş taht köşkü (B. Ögel)

Uygurlar; Kuça, Beşbalık, Turfan, Kızıl, Kumtura, Yarhoço, Murtuk, Bezeklik gibi şehirler kurmuş, bunları Maniheist ve Budist etkiler doğrultusunda birer sanat merkezi haline getirmişlerdir. Türk resim sanatının en zengin grubunun ortaya konduğu bu süreçte, düzleştirilmiş duvar üzerine bazen de yaş sıva üstüne belirli bir plana göre dizilerek işlenmiş resimler yapılmıştır. Başta Buda öğretisi ve hayatı olmak üzere dinsel konular, Buda'ya çiçek adağı yapan prens ve prenses tasvirleri bu betimlemelerin konuları arasındadır. Bunlardan Bezeklik 19 numaralı tapınakta (Çoruhlu, 2013, s. 255-280) yer alan duvar resimlerinde ellerinde lotus çiçeği tutan prens ve prenseslerin, ortalarından dügümlenerek iki yana asılmış perdelerin arasında yer alması, perdenin Uygur dekorasyonunda ve süslemelerinde yer aldığını kanıtlamaktadır (Görsel 6, 7).

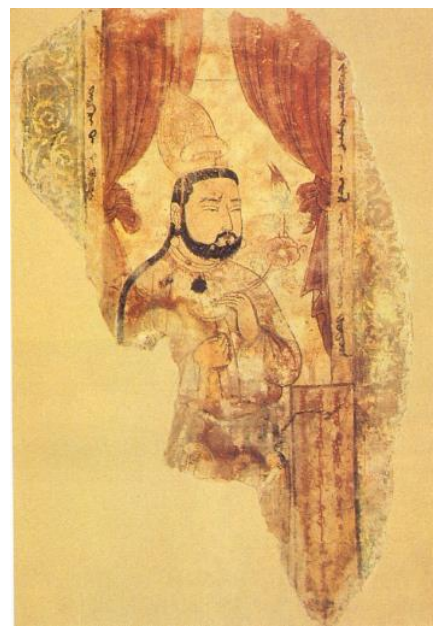

Görsel 6. Perdelerin arasina konumlandırılmış Uygur Prensi

(Y. Çoruhlu)

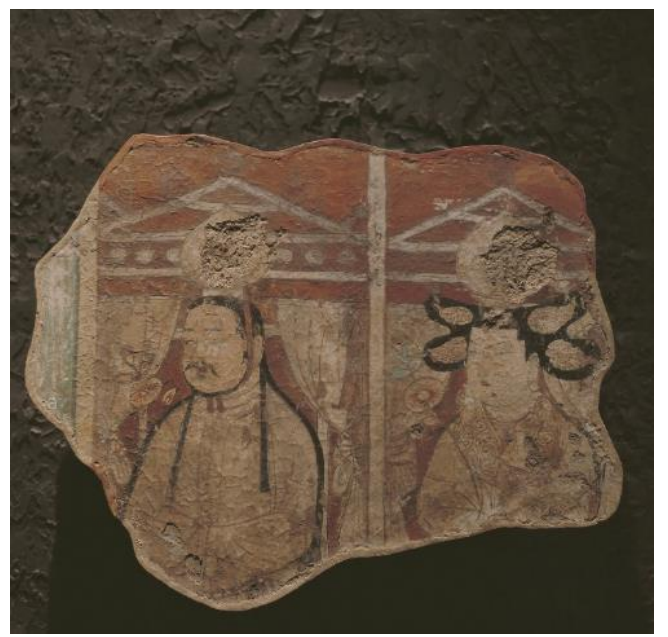

Görsel 7. Perdeler arasında betimlenmiş Uygur Prens ve Prensesi (Y. Çoruhlu)

Soğdiana'da, başkent Balasagun olmak üzere kurulan Karahanlılar (840-1212) ve Gazne merkezli olarak varlık gösteren Gazneliler (913-1186) dönemlerinde, yerleşik yaşama geçişin artmasıyla birlikte, imar faaliyetlerinin hız kazandığı, çok sayıda dini ve sivil yapının ortaya konduğu bilinmektedir. Ancak bu süreçlerde kullanılan malzemenin büyük çoğunluğunu pasha ve kerpiç gibi dayanıksız malzemenin oluşturması birçoğunun 
günümüze ulaşmasını engellemiştir (Cezar, 1977, s. 98; Merçil, 1996, s. 480-483). Günümüze herhangi bir bulgu ulaşmamış olmakla birlikte, Karahanlıların, arklarda donattıkları korularında kafesli pencereleri ve renkli camları olan köşklerinde (Esin, 1975, s. 4; Cezar, 1977, s. 379), Gaznelilerin de dikdörtgen formlu ya da yuvarlak kemerlerle taçlandırılmış açıkıklarla iç mekânlarını aydınlattıkları Leşker-i Bazar gibi saraylarında (Aslanapa, 2011, s. 47) Uygur geleneğini sürdürerek, ihtişamı arttırmak ve mahremiyet sağlamak gibi amaçlarla perdeden istifade ettikleri ve bunu süs unsuru olarak kullandıkları tahmin edilebilir.

Cend merkezli bir beylik olarak Selçuk Bey tarafından kurulan İran Selçukluları, ilerleyen yıllarda Horasan ve Nişabur'u ele geçirerek siyasi merkez yapmış ve büyük bir devlet olarak varlık göstermişlerdir (Sümer, 2009b, s. 365-367). Merv, Rey, Isfahan, Belh, Herat, Kazvin, Kum gibi İran şehirlerini sosyo-ekonomik açıdan kalkındıran ve kültürel açıdan geliştiren Selçuklular (Cezar, 1977, s. 283; Özgüdenli, 2009, s. 375; Aslanapa, 2011, s. 89), bu şehirlerin bazılarına Orta Asya geleneğini sürdüren dört eyvanlı, avlulu köşkler ve saraylar inşa ettirmişlerdir (Esin, 1975, s. 4; Cezar, 1977, s. 290; Arık, 2017, s. 73). Bu sarayların özellikle taht odasına önem verdikleri ve duvarlarını bitkisel süslemeler, geometrik şekiller ve figürlerle donattıkları bilinmektedir (Arık, 201, s.96).

Selçuklu Sultanlarının taht odalarını gösteren tasvirler, 1306-10 yılları arasında Reşidüddin Fazlullah Hamedâni tarafından kaleme alınan Cámiu-t-Tevárih isimli yazma eserde görülür (İndirkaş, 2002, s. 137, 141). Neredeyse aynı kompozisyon şemasına sahip olan tasvirlerde, Sultan Alp Aslan, Sultan Melikşah, Sultan Sancar, Berk Yaruk gibi Selçuklu Sultanları tahtta otururken gösterilmiştir. Minyatürlerin çalışmamız açısından önem taşıyan noktası bünyelerinde bulundurdukları perde motifleridir. Minyatürlerde, tahtında bağdaş kurmuş şekilde oturma pozizyonunda tasvir edilen sultanların üst kısımlarının perde ile dekore edildiği görülür. Bu düzenlemeden yola çıkarak, taht odasının dekorasyonunda Türk geleneğinin sürdürüldüğü ve perdenin değerli bir unsur olarak süsleme amaçlı olarak kullanıldığı söylenebilir (Görsel 8). Söz konusu tasvirlerde perdenin hemen sultanın üstünde olacak şekilde nakşedilmesi, bunun hükümdarlık alametlerinden biri olduğunu düşündürebilir. Bu uygulama, Uygur dönemine tarihlendirilen Bezeklik duvar resimlerinde yer alan prens tasvirlerinde de karşımıza çıkmaktadır. Uygur fresklerinde hükümdarların, genellikle iki yanına ya da üstüne perde asılması, düşüncemizi doğrular niteliktedir.

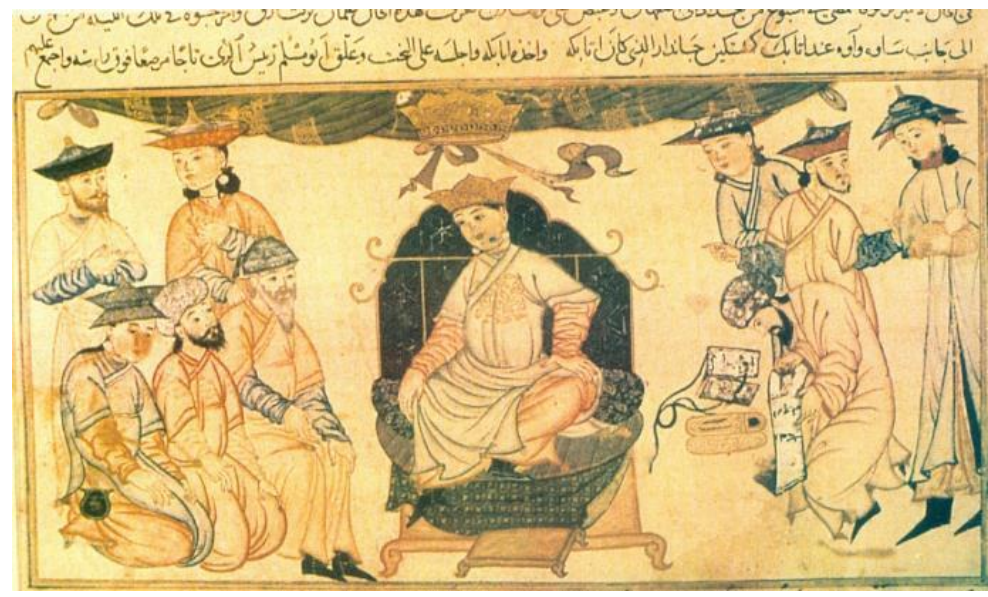

Görsel 8. Sultan Berk-Yaruk İbn Malik Şah (Z. İndirkaş) 
Yine Büyük Selçuklular zamanında İran Keşan'da yapılmış 1187 tarihli sırlı kâsede perde örgesine yer verildiği görülmektedir. Bünyesinde barındırdığı ağaç ve hayvan tasvirleri nedeniyle bahçe ortamı hissini uyandıran bu eserde (Görsel 9) bazı figürlerin, başlarındaki taçları sebebiyle saray erkânından oldukları izlenimi edinilmektedir. Söz konusu kişilerin üstlerinde, hükümdarlık alametlerinden biri olan ve çetr (gölgelik) olarak kullanılan perdeye yer verildiği görülür (Ögel, 1978a, s. 241).

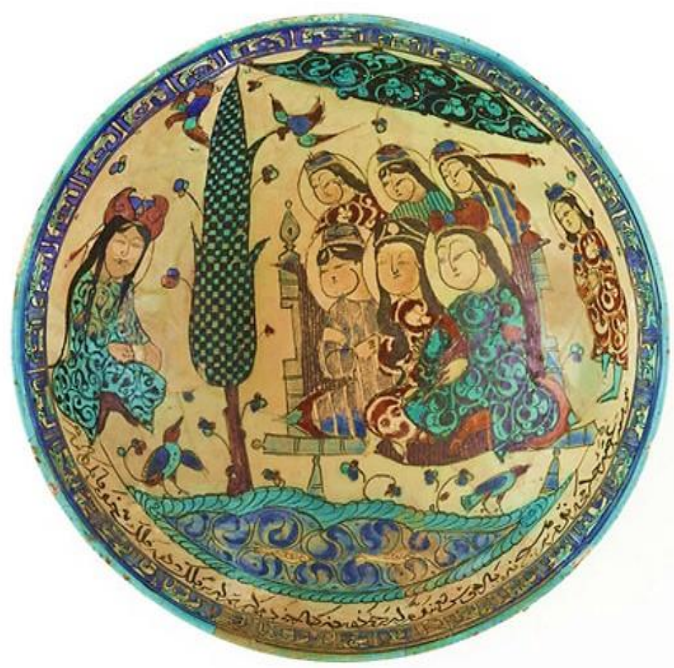

Görsel 9. Kâse

https://tr.pinterest.com/pin/490610953128581164 [Erişim:01.06.2019]

1961 yılında Diyarbakır İç Kalesinde yapılan kazılar sonucunda (Aslanapa, 2011, s. 101), Artuklular'a (1098-1234) ait bir saray kalıntısı ortaya çıkarılmıştır (Esin, 1975, s. 4; Aslanapa, 2011, s. 101). Günümüze ulaşmayan bu yapı topluluğunun birçok oda ve salondan oluştuğu ve cephelerinde pencerelere yer verildiği kaynaklarda yer alır (Arık, 2017, s. 123). Tasvir içeren yazma eserlerin, seramiklerin ya da ahşap parçaların sınırlı olması, bu süreçte dekorasyon ya da süs unsuru olarak perdenin kullanıldığına dair fikir üretmemizi zorlaştırmaktadır.

Kutalmışoğlu Süleyman Şah önderliğinde, İznik merkezli olarak kurulan (Türkiye) Selçuklu Devleti (1075-1308) zamanında (Sevim-Merçil, 1995, s. 422), siyasal ve sosyal anlamda gerekli düzenlemeler yapıldıktan sonra kültürel faaliyetlere girişilmiştir (Sümer, 2009, s. 381). Kültürel çalışmaların konumuza 1şık tutan önemli bir grubunu yazma eserlerde bulunan minyatürler oluşturur. Söz konusu yazma eserler, yalnızca içerdikleri bilgilerle değil, bünyelerinde barındırdıkları tasvirlerle de dönem yaşantısına ışık tutmaları açısından önem taşımaktadır.

Anadolu Selçukluları devrinde resimlenen yazmalardan birisi Varka ve Gülşah'tır. Bu yazmanın resimli tek nüshası, günümüzde Topkapı Sarayı Müzesi'nde yer alır (İnal, 1995, s. 49-50). Bünyesinde yer alan minyatürlerden birinde, Gülşah, çadırda otururken gösterilmiştir. Çadırın sağ tarafında başı haleyle çevrelenmiş bir kadına ve solda ise birbirlerinin kuyruğunu ısıran iki kediye yer verilmiştir (Görsel 10). Tasvirin çalışmamız açısından dikkat çeken kısmı, çadırın pembe renkli bir perdeyle taçlandırılmış olmasıdır. Söz konusu düzenleme, Anadolu Selçukluları döneminde perdenin günlük hayatta kullanılan 
bir unsur olduğunu ve dekorasyonda yer tuttuğunu göstermesi açısından önem taşımaktadır. Bunun yanı sıra Türkiye Selçukluları döneminde câme-bâf, nessâc, bâfende olarak tanımlanan dokumacı gruplarının var olduğu ve bunlardan câme-bafların kumaşın yanı sıra perde dokudukları da kaynaklarda geçmektedir (Merçil, 2000, s. 18-19).

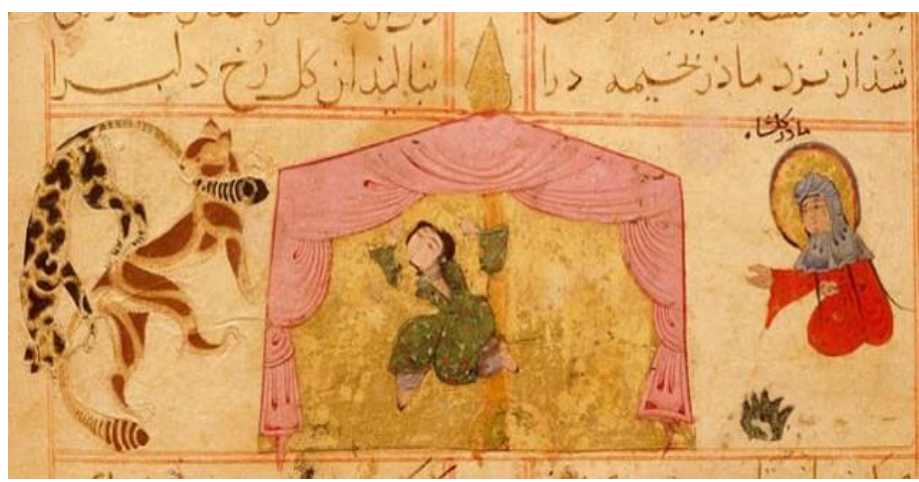

Görsel 10. Gülşah'ın Çadırda Üzülmesi (Y. Çoruhlu)

$\mathrm{Bu}$ süreçte Násirüddin Muhammed tarafından yazılan bir diğer yazma eser ise Dakáiku'l Hakáik (Gerçeklerin Ayrıntıları)'tir (Görsel 11). Farsça olarak yazılan eser; gök cisimleri, hayali yaratıklar ve büyü gibi konuları içermektedir. Bu yazmada; deniz, yeryüzü ve cennetin bir arada tasvir edildiği "Dünya'nın Sınırı" isimli minyatürde en üstte yer alan ve mavi renkle betimlenen cennete, yuvarlak kemerle taçlandırılmış önünde kanatları olan bir kapıdan girildiği görülmektedir (Pancaroğlu, 2015, s. 584). Bu uygulama, Anadolu Selçuklu dönemi sivil mimarisinde belirli açıklıkların ahşap kapaklarla kapatıldığına işaret etmekle birlikte bunların perde yerine de kullanıldığını varsaymak mümkündür. Cennete kanatları olan bir kapıdan geçerek girileceği düşüncesi, ilerleyen süreçte mihraplara işlenecek olan perde motifinin sembolizmini de bünyesinde barındırmaktadır.

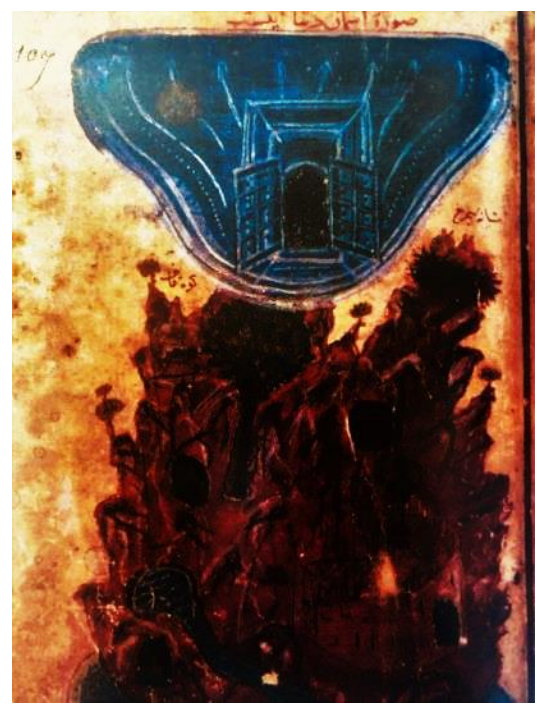

Görsel 11. Dünyanın Sınırı (O. Pancaroğlu)

Anadolu Selçuklu Devleti'nin Moğol saldırıları sonucunda dağılması ile Karamanoğulları, Candaroğulları, Dulkadiroğulları, Osmanoğulları gibi beylikler teşekkül etmiştir. Bu süreçte, Anadolu'da, taş temeller üzerine, ahşap çatkılı, kerpiç dolgulu profan yapılar inşa edildiği bilinmekle birlikte sürece ait sivil mimari örnekleri günümüze 
ulaşmamıştır (Kuban, 2018, s. 7). Yapıların pencere düzenlemeleri ve bunları kapatmak için kullanılan unsurların geleneğin devamı olduğunu tahmin etmek zor değildir.

$\mathrm{Bu}$ beylikler arasında yer alan ve ilerleyen süreçte Dünya İmparatorluğu olan Osmanlılar mimari, süsleme, kitap sanatları gibi birbirinden farklı alanlarda ortak üslup anlayışına sahip göz alıcı eserler ortaya koymuştur. Dönemi ele alan yayınlarda, Osmanlı evlerinin İslami gelenekler doğrultusunda şekillendirildiği, bunların mahremiyet duygusu sebebiyle duvarlarla kuşatıldığı ve pencerelerinin kafeslendiği (Kuban, 2018, s. 14), yanı sıra tahta kepenklerden istifade edildiği belirtilmektedir (Esin, 1975, s. 6; Kuban, 2018, s. 119). Henüz büyük boyutlu camların üretilmemesi, pencerelerin küçük camlar ya da önceden olduğu gibi yağlanmış kâğıtlarla kapatılması geleniğinin devamını sağlamıştır (Kuban, 2018, s. 121,122). Mimarideki bu kurguyla birlikte iç mekânda göçer gelenekler doğrultusunda halı, kilim gibi dokumalardan istifade edilmiştir (Kuban, 2018, s. 193) Bu bilgileri, yazma eserlerde gerçekçi bir yaklaşımla ele alınmış ve pek çok ayrıntı içeren minyatürler doğrulamaktadır. Erken ve Klasik dönemlere tarihlendirilen pek çok tasvirde, mekân kurgusu oluşturma isteği sütun, kemer, kubbe gibi mimari unsurların yanı sıra halı, perde gibi mefruşat ürünlerinden yararlanma gerekliliğini beraberinde getirmiştir. Pencereleri kapatmak için de perde gibi unsurlardan istifa edildiği minyatürlerden anlaşılmaktadır.

II. Bayezid dönemi yazmalarından biri XIV. yüzyılda İranlı şair Emir Hüsrev Dehlevi tarafından yazılan Hamse'nin, Heşt Bihişt adlı mesnevisidir. Yazma, ava düşkünlüğüyle bilinen Behram Gur'u ve onu bu zafiyetinden vazgeçirme amacını konu edinmiştir. Buna göre yedi farklı renkte yedi köşk inşa edilmiş olup her birine de birer prenses yerleştirilerek Behram'ın onlarla vakit geçirerek avı unutması amaçlanmıştır (And, 2017, s. 40). Siyah Köşk ismini taşıyan tasvir (Görsel 13), belirtmiş olduğumuz sivil mimari kurguyu yansıtmakla birlikte perde unsurunun kullanıldığı en erken örneklerden biridir. Minyatürün merkezinde yer alan prenses ve Behram Gur'un arkasında yer alan mavi çatılı ve kubbeli iki katlı köşkün, birinci katı kalın bir duvar gibi diğer birimleri çevreleyecek şekilde tasarlanmış ve ortada geniş iki yanda dar pencerelerle hareketlendirilmiştir. Dar olanlarda işlemeli kapaklar kullanılırken, kare biçimli, sarı söveli geniş pencerede, pililerle hareketlendirilmiş ortasından dügümlenerek sol tarafa asılmış yeşil perdeye yer verilmiştir.


Görsel 13'ten kapak ve perde detayları

Görsel 13. Siyah Köşk (M. And)

SEFAD, 2021; (45): 271-294 
Yine bu dönemde istinsah edilmiş yazma eserlerden bir diğeri Hâtıfî̀nin Şirin û Hüsrev adlı mesnevisidir. New York Metropolitan Müzesi İslami Eserler seksiyonunda yer alan ve XV. yüzyılın sonuna tarihlendirilen nüshasında bulunan minyatürlerde Osmanlı Dönemi evleri betimlenmiştir. Yazmada Şapur'un, Şirin'i gizli bir şekilde izlerken tasvir edildiği bir minyatürde (Bağc1 vd, 2006, s. 44, 45) (Görsel 12) yer alan mimari kurgu, bize Uygur devri köşklerini hatırlatır. Kademeli yükselişe sahip tasarımı olan köşkün, üç katlı olduğu ve her katında da aydınlık mekân yaratmak amacıyla pencerelere yer verildiği görülür. Buradaki önemli husus köşkün ikinci ve üçüncü kat cephe köşelerinin dekorasyonunda tıpkı Uygur köşklerinde olduğu gibi perdelerden istifade edilmesidir (Görsel 3). Kare forma sahip birimler dört köşede, ortalarından bağlanmış farklı renklere sahip perdelerle desteklenmiştir. Bu düzenleme, Osmanlı'nın erken döneminde perdenin dekorasyon unsuru olarak değerlendirildiğini göstermesi açısından önemlidir.

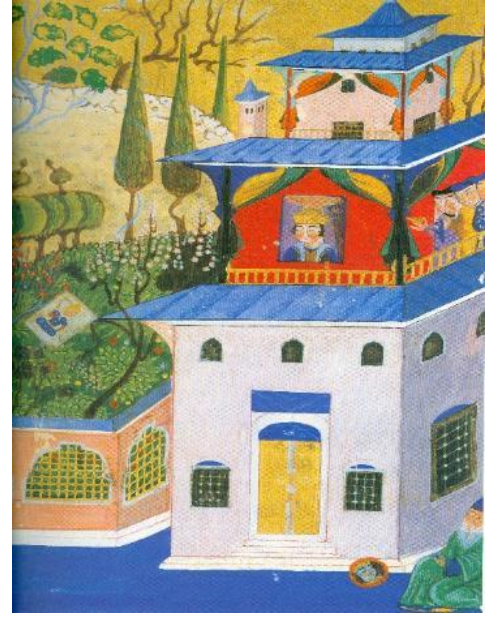

Görsel 12. Şapur, Şirin'in köşkü önünde

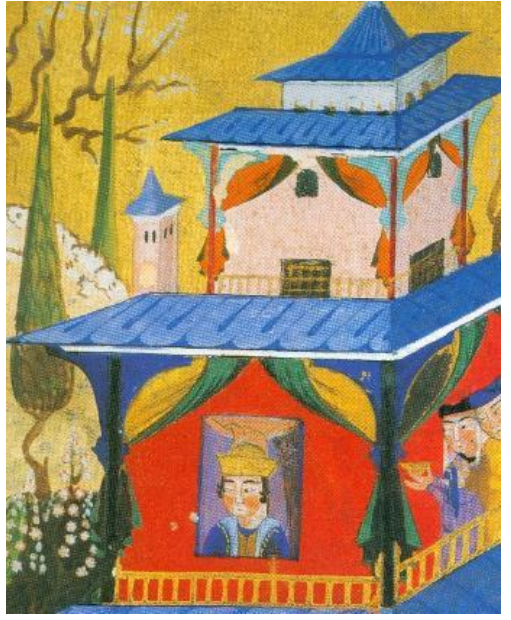

Görsel 12'den perde detayları

(S. Bağc1 vd.)

Perde motifinin Osmanlılar zamanında kullandığına dair betimlemelerden bir diğeri Hünername'de karşımıza çıkmaktadır. Topkapı Sarayı Müzesi Hazine Kitaplığında 1523 numara kaydıyla karşımıza çıkan bu yazma eser bilindiği gibi III. Murad'ın emriyle 15791580 yıllarında Seyyid Lokman tarafından kaleme alınmış ve minyatürleri de Üstad (Nakkaş) Osman ve ekibi tarafından nakşedilmiştir (Ertuğ, 1998, 484). Kuruluş devri ve onu müteakiben Kanuni Sultan Süleyman dönemine kadar olan süreci ele alan Şehname niteliğindeki bu eserde Nakkaş Osman tarafından betimlenen II. Mehmed'in Edirne'de cülusunu (Görsel 14) itina ile konu edinen minyatürde; Padişah merkeze alınmış ve saray erkânı da hiyerarşik düzende, simetrik şekilde onun iki tarafına yerleştirilmiştir. Burada konumuz açısından dikkat çeken nokta, perde unsurunun Fatih Sultan Mehmed'in her iki yanına asılmış olarak ele alınmasıdır. Bu vesileyle bir iç mekân görüntüsü de elde edilmiştir. Kırmızı renkte verilen perdelerin penç desenleriyle tezyin edilmesi dikkat çeken diğer bir noktadır ki bu yaklaşım, nakkaşın ayrıntıya verdiği önemin göstergesi olmakla birlikte, saraydaki mekân düzenlemesini gerçekçi bir şekilde ortaya koyması açısından da önemlidir. Ayrıca Sultan'ın iki yanına perde asma uygulamasının da Uygur geleneğinin uzantısı olduğu aşikârdır (Görsel 6, 7). 


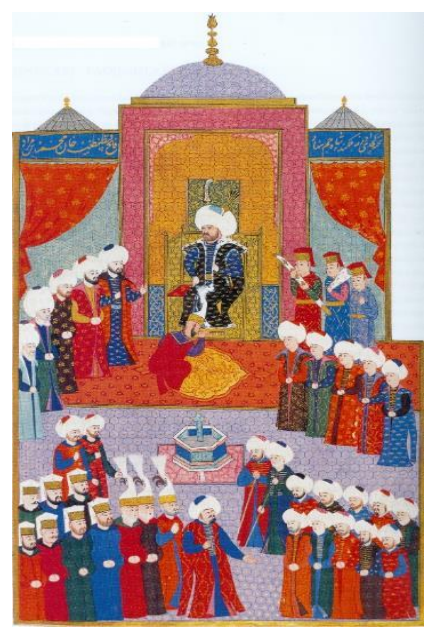

Görsel 14. II. Mehmed'in Cülusu

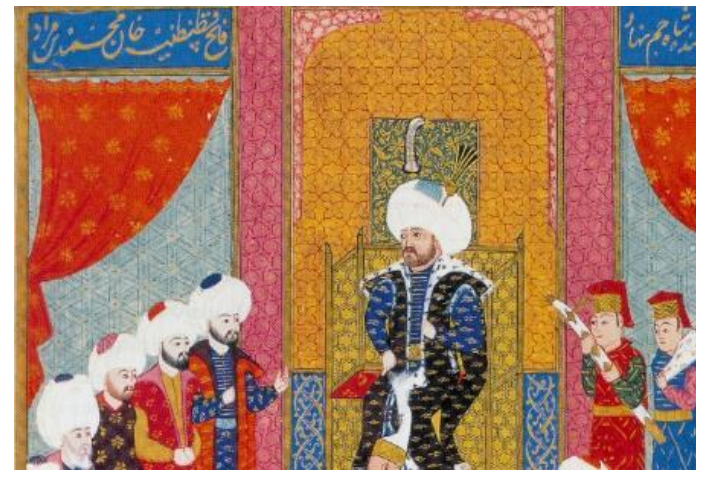

Görsel 14’ten detay

\section{(M. And)}

Bu süreçte, Seyyid Lokman ve Nakkaş Osman ekibi tarafından ele alınan bir diğer eser, Sultan III. Murad Şehinşahnamesi (Şehname-i Sultan Murad)'dir. XVI. yüzyıla tarihlendirilen ve toplam 95 minyatürü içeren iki ciltlik bu eser; Sultanların hayatlarını, seferleri, fetihleri, eğlenceleri, vezir kabullerini, ilmi çalışmaları konu edinmiştir (Aksu, 1981, s. 7-8). Söz konusu eserin ikinci cildindeki 1597'ye tarihlendirilen Bayramlaşma sahnesi (Görsel 15), konumuz açısından değerlidir. Çift sayfada tasvir edilen ve Osman Paşa'nın Sultan'ın divanına kabulünü gösteren minyatürün sağ tarafında Adalet Kulesi betimlemesi yer almaktadır (Bağcı vd., 2006, s. 153). Kulenin etrafını çevreleyen ve revak kısmını oluşturan sütunların, üst taraftan kırmızı zeminli, siyah konturlu, bombeli perdelerle süslendiği görülmektedir. Bu yaklaşım tarzı da aklımıza, Uygur evlerinin dış cephelerine estetik görünüm vermek amacıyla astıkları perdeleri getirmektedir.

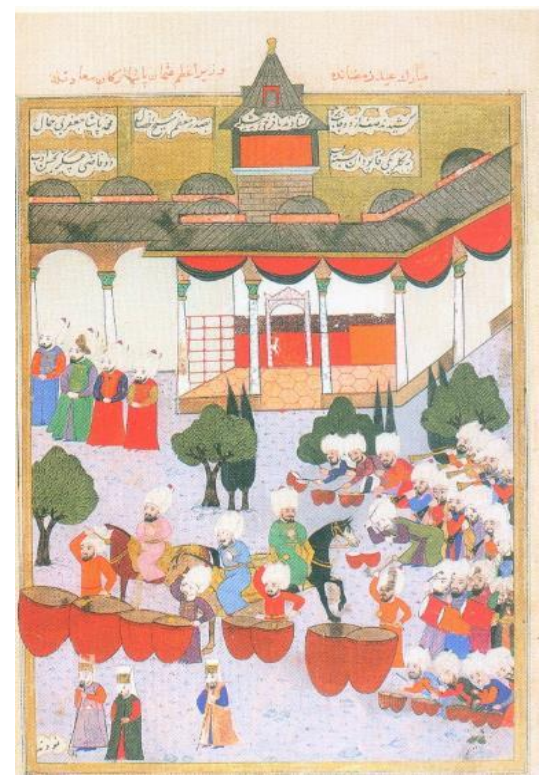

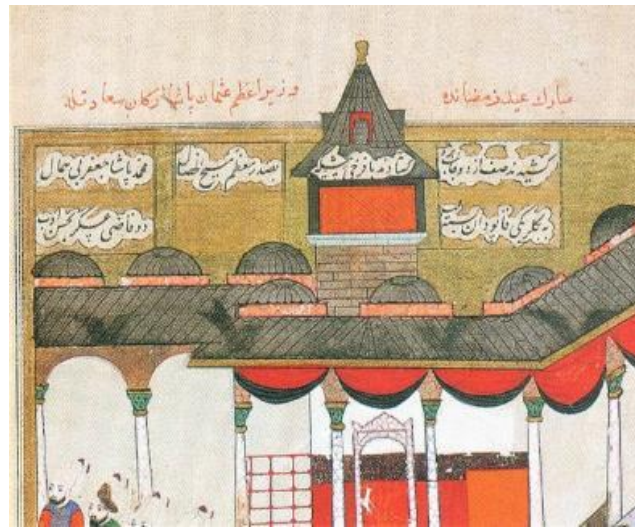

Görsel 15'ten detay

Görsel 15. Bayramlaşma (S. Bağc1 vd.) 
Şehinşahname II'de yer alan ve Vezir Mehmed Paşa'nın Şehzade Mehmed'in huzuruna çıkışını gösteren minyatürde harem ortamı tasvir edilmiştir (Görsel 16.) (Bağcl vd., 2006, s. 154). Burada dikkat çeken husus, duvara ve kapıların üstlerine asılan perdelerdir. Bunlardan biri; sol üstte yer alan, ana zemini kırmızı, üst ve alt kenarlarda şemse motifleriyle bezenen, lacivert renkli bordürlere sınırlandırılmış olanıdır. Bir diğeri hemen bunun sol alt köşesinde her iki yüzü kırmızı ve yeşil gibi farklı renklerle tasarlanmış ve büzülerek, kapının sol kenarına asılmış şekilde işlenmiştir. Seyirciye dönük kırmızı yüzde sarı renkte işlemelere yer verilmiştir. Üçüncü perde ise sağ sayfanın hemen merkezinde, kapının üst kısmında görülmektedir. Simetrik bir şekilde büzülerek, iki tarafa sarkacak biçimde tasvir edilen bu perdede de ana renk, kırmızı olup yüzeyi nakışlıdır. Dördüncü örnek ise hemen bu kapının solunda yer alan ve kapı görevi gören, üzerinde sarı desenler bulunan kırmızı zeminli olandır. Bu düzenleme saraya ait birimlerde dekorasyona önem verilmesini göstermesinin yanı sıra perdenin Osmanlı saray yaşamındaki yerini de ispatlamaktadır. İç mekân duvarlarına, kapılarına dokuma asma geleneğinin erken devir Türklerinden süregelen bir gelenek olduğunu söylemek mümkündür. Bilindiği gibi İç Asya'da hüküm sürmüş Türkler, yurt tipi çadırlarının kerege denilen ana iskeletini keçelerle kapladıktan (Çoruhlu, 2013, s. 120) sonra estetik görünüm elde etmek istemişler ve bunu gerçekleştirmek için de rengârenk yaygıları, hem çeperlere asmışlar hem de çadırın giriş kapısını bu dokumalarla perdelemişlerdir.

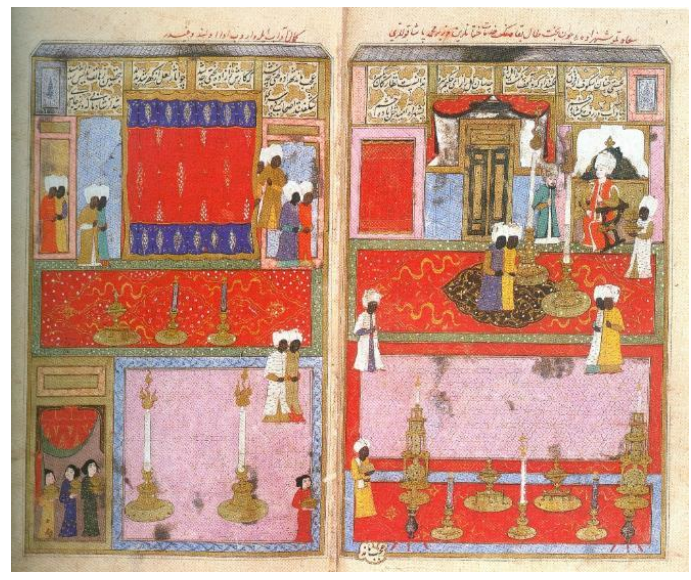

Görsel 16. Şehzade Mehmed'in Huzurundaki Vezir Mehmed Paşa (S. Bağcı vd.)
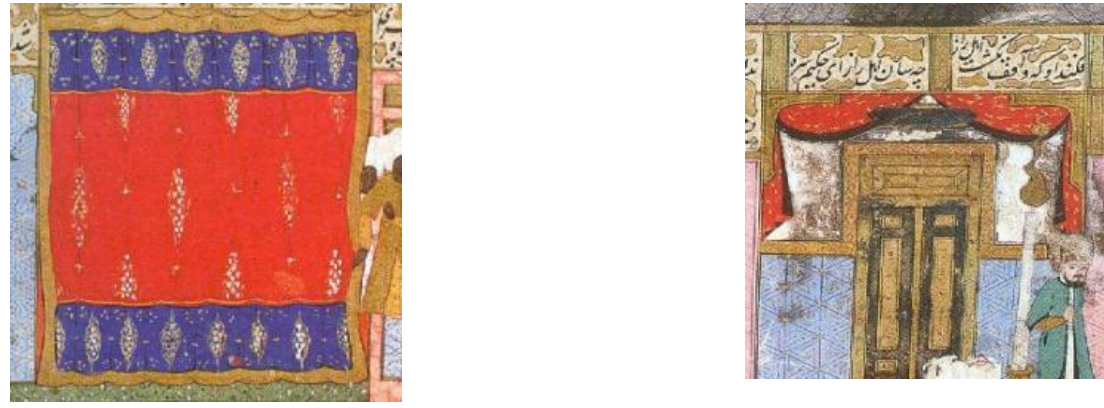

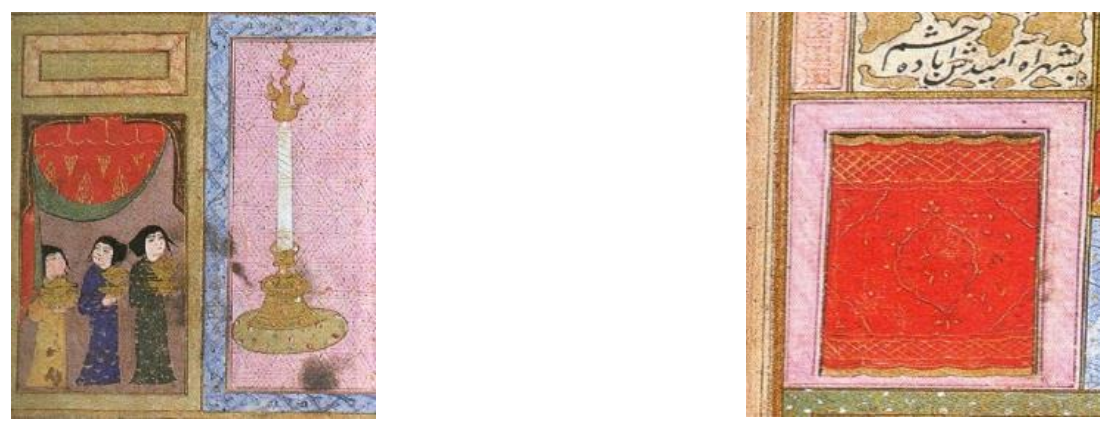

Görsel 16'dan detaylar

Ele geçen bulgular, söz konusu motifin kullanımının, minyatürlerle sınırlı kalmadığını göstermektedir. İznik'te yapılan kazılarda elde edilen ve Milet İşi olarak adlandırılan bir grup seramikte, bitkisel desenler ve figürlü süslemelerin yanında, mimari şekillerin de süsleme amacıyla değerlendirildiği görülmektedir. Buluntular arasındaki bir kâsede (Görsel 17), süsleme olarak bir köşk betimlenmiştir. İki katlı izlenimi veren ve ortasında gül pencere barındıran dikdörtgen formlu olarak tasarlanmış ve üstü soğan kubbe ile örtülmüş bu yapının, hemen önünde bir çıkmaya yer verilmiştir. Balkon şeklinde tasarlanan bu birimin görünen yüzeyi, Uygur köşklerinde olduğu gibi, perdeyi andıran bir kumaşla hareketlendirilmiştir.

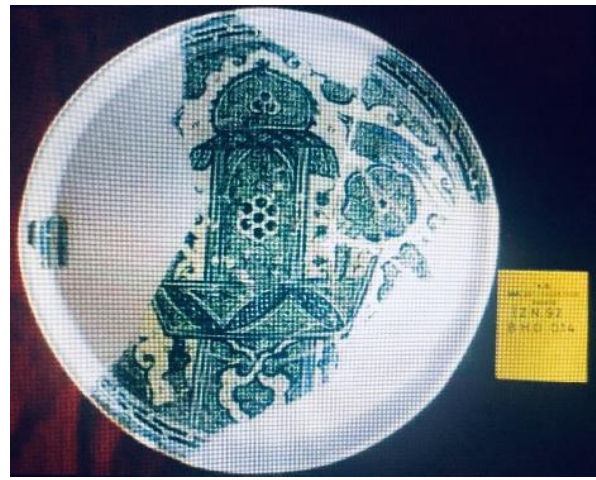

Görsel 17. Milet İşi kâse

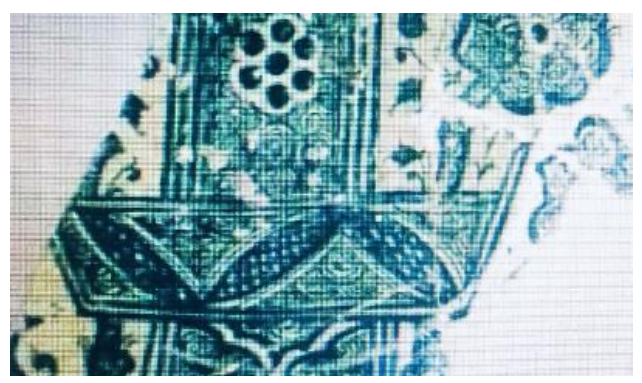

Görsel 17'den detay

http://www.antikalar.com/iznikseramikleri [Erișim: 05.07.2019]

Kanuni Sultan Süleyman zamanında (1520-66), Kırkçeşme sularının İstanbul'a dağıtımı amacıyla Eğrikapı'da sur dışında bir maksem inşa edilmiştir. Savaklar Çeşmesi olarak bilinen bu yapının, Mimar Acem Ali tarafından yapıldığı bilinmektedir. Söz konusu yapı; I. Abdülhamid, III. Selim, II. Mahmud zamanlarında onarım geçirmiştir (Ertuğrul, 1994, s. 496). Kare tabanlı olarak tasarlanan çeşmenin ön cephesinde, geniş bir yuvarlak kemerle oluşturulmuş niş içinde; mermerden dikdörtgen formlu bir ayna taşı mevcuttur (Görsel 18). Taş, bünyesinde barındırdığı süsleme unsurları ile klasik dönem özelliklerini taşımaktadır. Dört köşesinde stilize edilmiş bitkisel motiflere yer verilmiş ve iki tarafında palmet desenleriyle taçlandırılmış altıgen formlu kartuşun ortasındaki musluğun hemen üst kısmında da klasik dönem minyatürlerinde görülen perde motiflerini andıran bir tasarım, aşağı doğru sarkmış şekilde ve alçak kabartma tekniği kullanılarak işlenmiştir. Bu 
uygulama, taş eserlerde de süsleme amacıyla perdeden yararlanıldığını göstermesi açısından önemlidir.

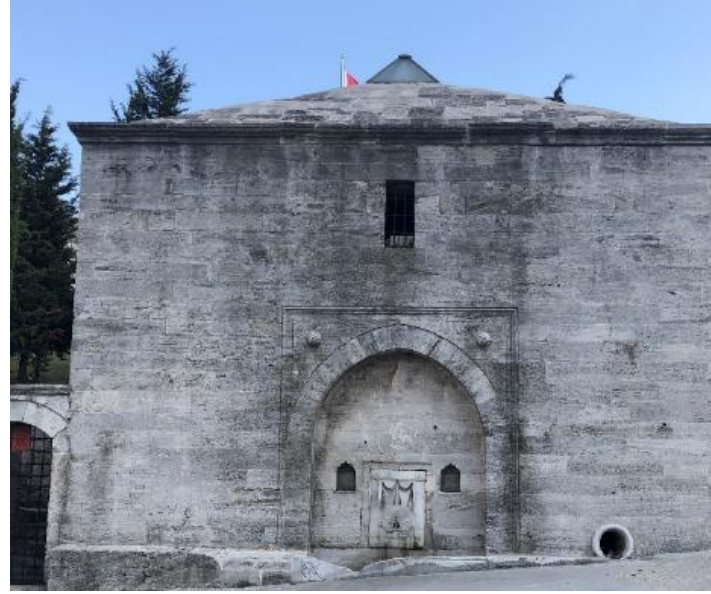

Görsel 18. Savaklar Çeşmesi

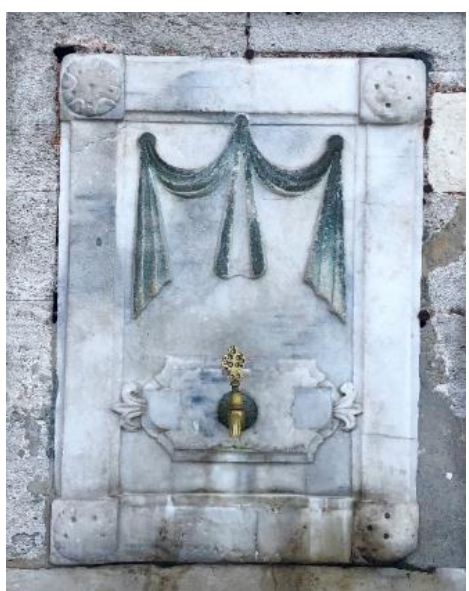

Görsel 18'den ayna taşı detayı

(Eğrikapı Maksemi)

Osmanlılar zamanında çini, ahşap, taş gibi malzemelerin yanı sıra boya ve fırçayla yapılan kalem işi bezemelerde süslemede kullanılmıştır. Uygulanan kompozisyonlarda bitkisel motiflerin yanında, mimari görünümler ve nesnel bezemelere de yer verilmiştir. Çalışmamız açısından dikkat çeken bir örnek, Topkapı Sarayı Harem Dairesi'nde bulunmaktadır (Görsel 19). 1600'lü yıllara ait olan bu bezemede, deniz kenarında bulunan ve çevresi duvarlarla çevrilmiş bir yalı tasvir edilmiştir. İki yanda simetrik şekilde konumlandırılmış merdivenlere sahip, iki katlı yapının, ön kısmına revaklı bir düzenlemenin hâkim olduğu görülmektedir. Arka fona ise geniş bir arazi, evler ve gökyüzü yerleştirilmiştir. Tüm manzara, üst kısma asılmış, iki boğumlu ve öncekilerden farklı olarak sağ taraftan sarkan bir perdeyle taçlandırılmıştır. Bu uygulama ile manzaranın, karşı taraftaki başka bir evin penceresinden izleniliyormuş hissi uyandırılmış ve resme derinlik kazandırılmıştır. İlerleyen süreçte oldukça sık bir uygulama alanı bulacak olan bu tarz görünümler, iç mekânın kapalı dünyasının dışarıya açılması şeklinde yorumlanmaktadır (Okçuoğlu, 2000, s. 50).

Yüzyılın son çeyreğinde gerçekleşen 1683 tarihli II. Viyana kuşatması, Osmanlı İmparatorluğu için bir dönüm noktası olmuş ardından on altı yıl sürecek savaşlar başlamıştır. Bu süreçte savaşlar için büyük harcamalar yapılması, Padişahların kısa süre görevde kalmaları gibi nedenler, Rumeli ve Anadolu'da gerçekleştirilecek inşa faaliyetlerini sınırlandırmış, ancak Saraçhanebaşı Amcazade Hüseyin Paşa Külliyesi ve Fatih Feyzullah Efendi Medresesi gibi küçük ölçekli yapılar inşa edilebilmiştir (Aslanapa, 1986, s. 425). Osmanlı İmparatorluğu'na geniş topraklar kaybettiren ve 1699 yılında imzalanan Karlofça Antlaşması ile son bulan savaşlar sonunda Osmanlılar, eksikliklerini fark etme fırsatı yakalamış, siyasi ve askeri alanda yenilikler yapılması gerekliliğini hissetmiş, atılacak adımlarla eski refaha kavuşulacağına inanmıştır (Özcan, 2004, s. 246-49). Rahata ulaşma yolunun, Avrupa'nın örnek alınmasıyla yapılacak reformlardan geçeceğine dair inanç neticesinde, Batı'yı tanıyan ve buradaki gelişmeleri yakından takip eden Sadrazam Nevşehirli Damat İbrahim Paşa görevlendirilmiştir. Bu doğrultuda yapılacak girişimler için gözlem yapması amacıyla Sultan III. Ahmed ve Sadrazam tarafından Yirmi Sekiz Çelebi 
Mehmed Efendi, Fransa'ya gönderilmiştir. Onun, beş aylık görevi süresince edindiği izlenimlerin, saray tarafından dikkate alınması sonucunda özellikle mimari ve askeri alanda yenilikler yapma yoluna gidildiği görülmektedir (Kuban, 2016, s. 506-507). Fransa etkisiyle meydanlar çeşmelerle zenginleştirilmiş, Sadabad; kanallar, bentler, havuzlar ve kasırlarla donatılmıştır. Söz konusu yapılar Safevi kültürünün uzantısı olan bitkisel bezemelerle tezyin edilmiştir. Lale Devri olarak adlandırılan bu süreçte, siyasi ve sanatsal açılımlar gerçekleşmiş ve ilerleyen süreçte, Osmanlı mimarisini de etkileyen batılı üsluplara geçiş dönemi oluşturulmuştur. Bu devrin belirgin süslemelerini; panolara hakkedilerek işlenen vazoda çiçekler, sepet içerisinde meyveler, çelenkler oluşturmuştur (Kuban, 2016, s. 509).



Görsel 19. Yalı Tasviri (E. Esin)

Lale Devri'nin sona ermesiyle 1735 yılından itibaren, Avrupa'da etkili olan Rokoko tarzı, mimariye yansımaya başlamış ve hemen ardından da Barok üslubun etkileri görülmüştür. İlerleyen süreçte, her iki stilin paralel bir şekilde mimariye uygulanması izlenir (Kuban, 2016, s. 505). Eğrisel hatlar, kırık kemerler, akantus yaprakları, S-C kıvrımları, istiridye motifleri, geniş saçaklar, derin yivlerle hareketlendirilmiş sütunlar, vitraylar bu süreçte yaygın kullanım alanı bulmuştur (Atasoy, 1992, s. 82-83). Burada dikkat edilmesi gereken husus Batı etkisiyle uygulanan motifler arasında perdenin olmamasıdır.

1804 yılında Fransa'da Antik Yunan, Roma ve Misır temelli olarak gelişen, kask, balta, silah, bayrak, davul, mask, zafer imgeleri gibi savaşı çağrıştıran bezemeleriyle İmparator Napoleon'un, Mısır ve İtalya'da kazandığı zaferleri sembolize etmek isteyen Ampir üslup ortaya çıkmıştır (Germaner, 1997, s. 88). Görüldüğü gibi Ampir üslubun temel bezemeleri savaş ve zafer odaklıdır. Bir mefruşat olarak perdenin, herhangi bir malzeme üzerine çeşitli tekniklerde bir motif olarak işlendiği görülmemekle birlikte, mekânı görsel açıdan daha alımlı hale getirmek amacıyla dekorasyonda kendine yer bulduğu söylenebilir.

1808 yılından itibaren Osmanlı mimarisinde etkisini göstermeye başlayan ampir üslup etkisini; Tophane Nusretiye ve Ortaköy Büyük Mecidiye camileri, Dolmabahçe ve Beylerbeyi sarayları, çeşitli köşk, konak, yalı gibi yapılarda göstermiştir (Kuran, 1997, s. 1397). Söz konusu yapılarda antik başlıklarla taçlandırılmış pâyelerle bölünen duvar yüzeyleri; Batı tarzında manzara resimleri, matematiksel aletler, çalgı takımları, askeri 
armalar, stilize edilmiş bitkisel süslemeler arasına gizlenmiş hayvan figürleri, çelenkler ve Türk kültürünün uzantısı olan perdelerle tezyin edilmiştir.

Türk kültürüyle sentezlenerek uygulanan Ampir üsluplu yapılardan biri olan 1826 tarihli Nusretiye Camii'nin son cemaat yeri mermer korkulukları (Görsel 20) ve minaresinde, kabartma tekniğiyle işlenmiş perde motifleri mevcuttur. Bunlar düzenleme açısından farklı Türk devletleri tarafından ortaya konan örneklerle benzerlikler taşımaktadır. Bir diğer örnek ise Ortaköy'de yer alan ve 1856 yılında inşa edilen Büyük Mecidiye Camii'dir. Yapının kubbesindeki kalem işi tekniğiyle yapılan pencere formundaki süslemelerin, yine aynı teknikle uygulanan kıvrımlı perdelerle desteklenmiş oldukları ve bu sayede üç boyutlu görünümler elde edildiği dikkat çekmektedir. Keza Sultan Abdülmecid zamanında yaptırılan Dolmabahçe Sarayı Muayede Salonu'nun kubbesinde de aynı uygulamaya yer verilmiştir (Görsel 21). Kocamustafapaşa Küçük Efendi Camii'nin dış duvarındaki II. Mahmud Çeşmesi'nin alınlık kısmında, iki yana sarkmış şekilde tasarlanan perde örgesi dikkat çekicidir. Bunların yanı sıra Fatih'te yer alan Nakşidil Sultan Türbesi'nin cephesinde görülen oval pencerelerin üst kısmında, İstanbul Deniz Müzesi bahçesinde yer alan Kaptan-1 Derya Cezayirli Gazi Hasan Paşa Çeşmesi ayna taşında (Görsel 22) kabartma teknikli perde motiflerine yer verilmiştir.

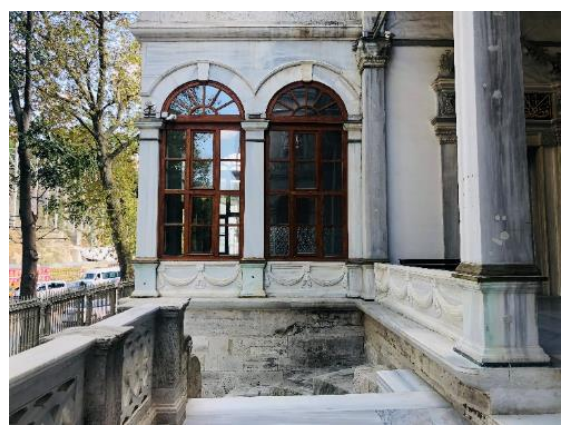

Görsel 20. Nusretiye Camii son cemaat yeri korkulukları

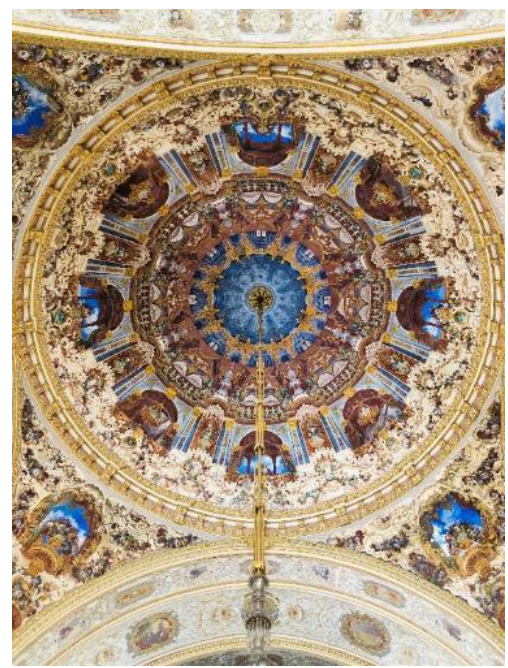

Görsel 21. Dolmabahçe Saray1

Muayede Salonu kubbesi

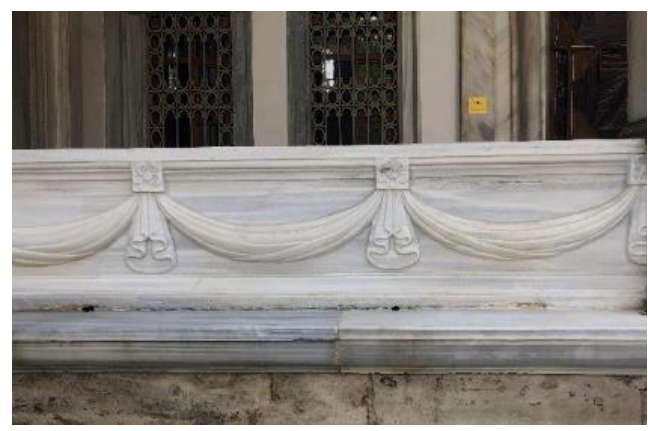

Görsel 20'den perde detayları

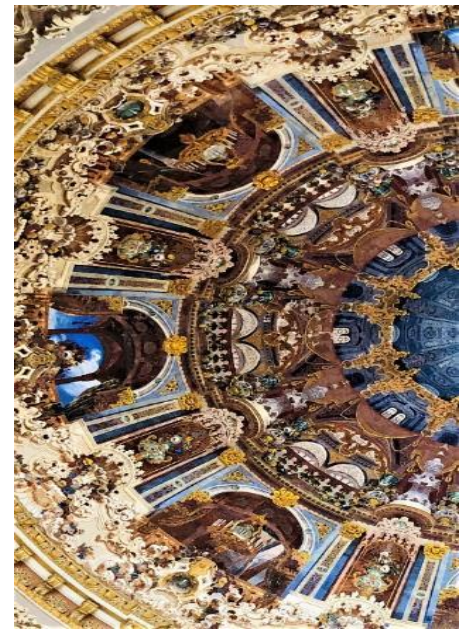

Görsel 21'den perde detayları 

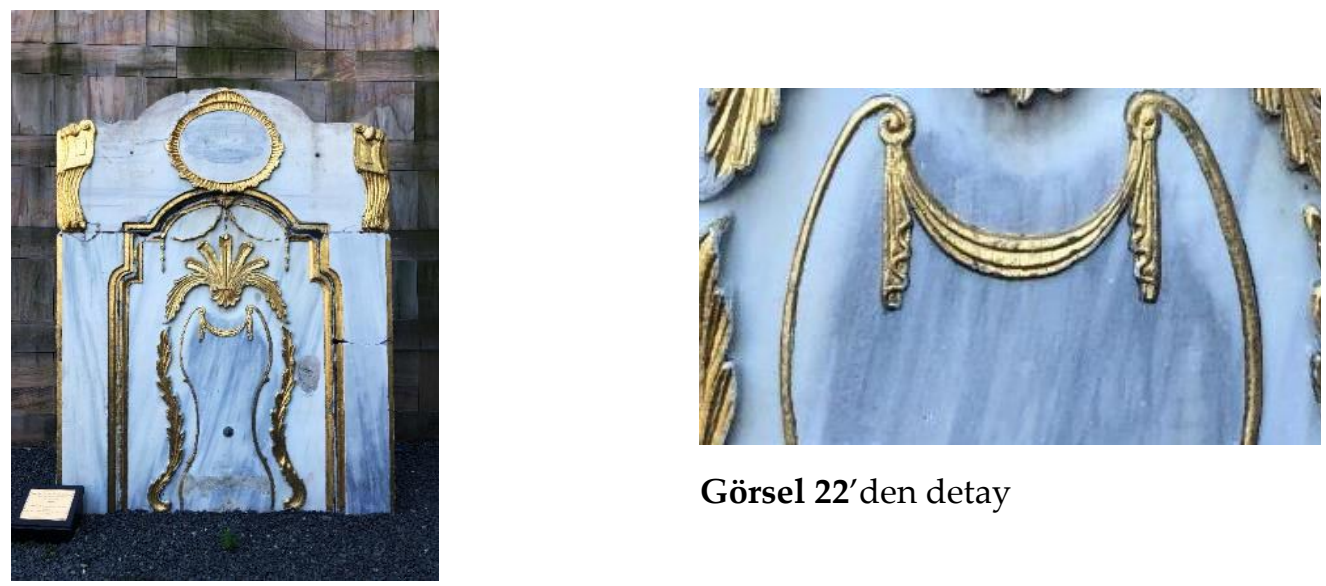

Görsel 22'den detay

Görsel 22. Kaptan-1 Derya Cezayirli

Gazi Hasan Paşa Çeşmesi ayna taşı

Sultan I. Ahmed Han'ın ayakta, bir masaya yaslanmış şekilde tasvir edilmiş olduğu renklendirilmiş gravür örneğinde (Duran, 1999, s. 148), hemen Sultan'ın sol arkasında oldukça kalın bir kumaştan imal edilmiş olduğu izlenimi uyandıran bir perde yer almaktadır. Ortamın ihtişamını arttıran ve resme derinlik katan perde motifi, kurgusu itibariyle Uygur dönemi süsleme anlayışını hatırlatmaktadır.

Reformist padişahlardan biri olan Sultan Abdülmecid'in (1839-1861), Eyüp Sultan'dan Saraya dönüşünü betimleyen Mevlut Alayı (Duran, 1999, s. 272) isimli tablonun ayrıntılarında perde motifleri dikkat çekmektedir. Tablonun merkezine alınan Padişahın iki yanına diagonal eksende asker grupları yerleştirilmiş ve bu şekilde derinlik etkisi yaratılmıştır. Kompozisyonun solunda Eyüp Külliyesi görülürken sağ tarafta mimari ile aynı düzlem üzerine yerleştirilmiş sıra evler mevcuttur. Sıra evlerin pencerelerinde, daha önce bahsettiğimiz ve mahremiyet duygusuyla kullanılan kafes örgülerin arkasında perde motifleri işlenmiştir.

Perde motifinin kullanımının İstanbul ile sınırlı kalmadığı, Anadolu'da pek çok camide kendine yer bulduğu yapılan araştırmalarla ortaya konmuştur. Cincin Cihanoğlu, Acıpayam Yazır, Akköy Yukarı, Baklan Boğaziçi, Civril Savranşah, İzmir Orhan, Kula Emre Köy camileri (Yurtsal, 2009:136), Bursa Ulu, Yıldırım Bayezid, Hüdavendigar camileri, Osman Gazi, Orhan Gazi, Gülruh Hatun türbeleri, Sakarya Geyve'de Elvan Bey İmareti, Bozören Eski ve Bağcaz köyleri camileri, Akyazı Çengeller ve Boztepe Çatalkaya camileri (Çoruhlu-Alkan, 2017, s. 898-908), Uşak Merkez Ulu, Karaali, Kurşunlu, Boduroğlu, Cinibiz (Gürsoy, 2015, s. 150) gibi çok sayıda eserde perde örgesine yer verilmiştir. Söz konusu örneklerin büyük bir kısmı mihrap nişine işlenmiş olarak karşımıza çıkar. Bu uygulama perdenin, simgesel olarak bu dünya ve öteki dünyayı birbirinden ayırması, bu âlemden öteki âleme geçiş şeklinde yorumlanmaktadır (Okçuoğlu, 2000, s. 51).

Motifin, Çağdaş Türk resminde de ele alındığı görülür. Feyhaman Duran, Şevket Dağ, Mihri Müşfik Hanım, Hoca Ali Rıza Efendi gibi sanatkârlar, resimlerinde süs unsuru olarak perdeye yer vermiş ressamlarımızdan bazılarıdır.

Türk resminin önde gelen temsilcilerinden biri Şevket Dağ'dır (1876-1944). İstanbul'u işlediği çalışmalarında; dinsel mekânları, sokakları, evleri, mesire yerlerini büyük bir ustalıkla ele almıştır. Onun, konularının önemli bir grubunu da Boğaziçi görüntüleri 
oluşturmaktadır. Bunlardan birinde, Boğaz'a nazır bir evin içinden karşı kıyının tasvir edildiği görülür. İç mekân (enteriyör) ressamı olarak da tanınan Dağ'ın (Giray, 2009, s. 88), burada bir dekorasyon unsuru olarak perdeye yer vermesi dikkat çekicidir. Üzerinde rengârenk minderlerin bulunduğu sedir, kanatları iki yana açılmış pencerenin önüne konumlandırılmıştır. Sol taraftaki kanadın arkası boş bırakılırken, sağdakinin gerisinde, üstünde mavi desenler bulunan hafif pilili bir perde mevcuttur. Osmanlı Saray hayatının yanı sıra sivil yaşamda da mefruşat olarak, perde kullanıldığını sunması açısından önemli bir örnektir (Görsel 23).

Devrin ileri gelenlerini ele aldığı portre ve figür çalışmalarıyla tanınan ve ilk Türk kadın ressamlarımızdan biri olan Mihri Müşfik'in (1886-1950?) (Arslan, 1997, s. 1244) Naile Hanım isimli yağlı boya tablosu da konumuz açısından dikkat çeken örneklerden biridir (Görsel 24). Resmin merkezine konumlandırılmış figür, oldukça gösterişli bir odada, sedir üzerinde otururken betimlenmiştir. Onun, hemen solunda ucunda püskülleri olan fon bağ1 ile sağ tarafa doğru ve üzerinde sarı renkli desenler bulunan mavi zeminli bir perdeye yer verilmiştir. Bilindiği gibi Naile Hanım, bir ayan reisi olan Ahmet Rıza Bey'in annesidir ve bu tablo, bir ayan evinin dekorasyonunu da bizlere sunması açısından önem taşımaktadır (Seyran, 2005, s. 66).

Görüldüğü üzere perde motifi, Türk sanatı içerisinde önemli bir yere sahiptir. Kullanımı geç dönemde artmış olmakla birlikte, Türklerin erken devirlerden beri her türlü eser üzerine incelikle işlediği bir bezeme unsuru olmuştur.

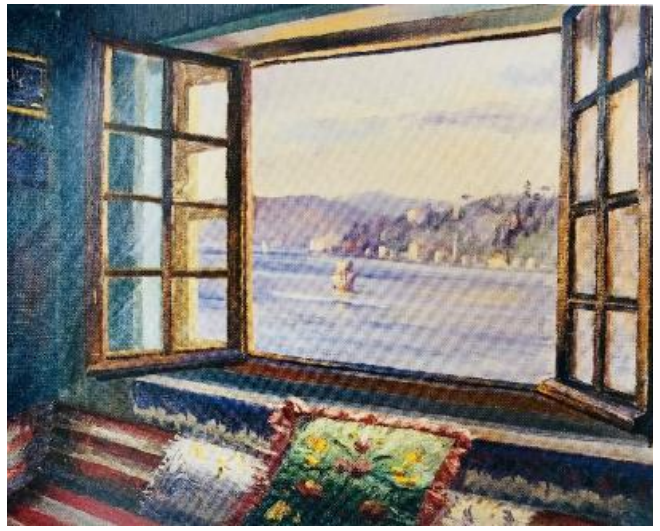

Görsel 23. Manzara

(K. Giray)

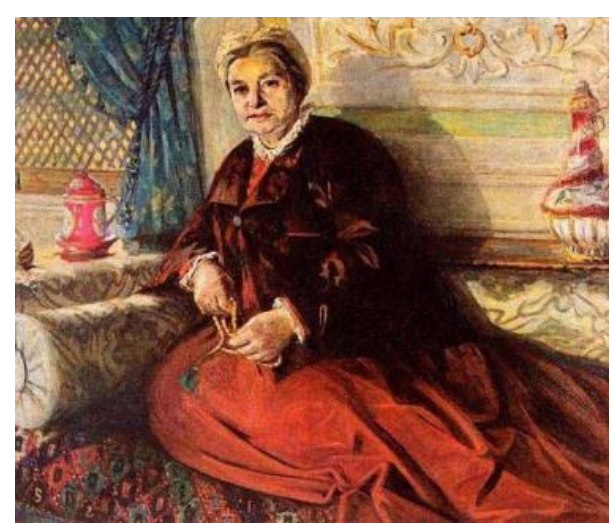

Görsel 24. Naile Hanım Portesi

(T. Toros)

\section{SONUÇ}

Türklerin; konar-göçer, yarı yerleşik ve yerleşik yaşam biçimlerini benimsedikleri ve bu süreçlerde, yurt adı verilen çadırları ya da kale tipi yerleşmeleri mesken olarak kullandıkları bilinmektedir. Uygurlar döneminde özellikle din değiştirmenin etkisiyle yerleşik kültürün kalıcı hale gelmesi iklim ve coğrafyaya göre şekillenen, çeşitli malzemeler kullanılarak yapılan ve bark olarak adlandırılan konutların inşa edilmesinin önünü açmıştır. $\mathrm{Bu}$ evlerin düşey yüzeylerine, havalandırma ve gün ışığından yararlanma ihtiyaçları doğrultusunda, farklı formlara sahip pencereler açılmıştır. Bunlar; soğuktan korunma isteği ve mahremiyet duygusu gibi sebeplerle camın keşfine kadar ahşap kapak, dokuma veya yağlı kâğıtla kapatılmışlardır. Yaşanılan bu meskenlere, estetik görüntü kazandırma isteği 
göçer kültür uzantısı olan dokuma geleneğinin sürdürülmesini sağlamış ve barklar çeşitli mefruşat unsurlarıyla dekore edilmiştir. Kullanılan mefruşat unsurlarından biri de perde olmuştur. Bu unsur, yalnızca ilgili alanda kullanılmamış; binaların dış cephelerine, yataklara, hükümdar tahtlarının üstlerine ya da tahtların arkalarına da asılmış ve ortama, zengin bir görünüm ve kutsiyet kazandırmıştır. Zamanla kullanım eşyası olmanın ötesine geçen perde; duvar resimlerinde, seramikte, minyatürde, resimde, gravürde ve mimaride bir tezyin unsuru olarak değerlendirilmiş ve Türk tezyinatında, Orta Asya Türklerinden Osmanlı İmparatorluğu'nun son dönemine kadar uzanan süreçte sıklıkla kullanılan motiflerden biri olmuştur.

En erken tasvirlerini Uygur döneminde gördüğümüz motif, genellikle duvar resimlerinde ele alınmış, özellikle tahtın bulunduğu ortama ya da prens ve prenses figürlerinin iki yanına süsleme unsuru olarak yerleştirilmiştir. Aynı uygulama, İran ve Anadolu Selçukluları süresince ortaya konan eserlerde de uygulanmış keza çadırlarda da üst örtü olarak değerlendirilmiştir. Osmanlı devri süsleme sanatında da, Uygur geleneği devam ettirilmiş, bilhassa yapı cephelerinin dekorasyonunda perde kullanılmıştır. Bunun yanı sıra hükümdar tasvirleri ve saray birimleri de perde nakşı ile desteklenmiştir. Mimari etkiyi arttıran ve kalem işi tekniğiyle yapılan manzara tasvirlerinde ise sahneye derinlik kazandırmak amacıyla perde örgesinden istifade edilmiştir.

Geç dönem yapılarında ise yoğun bir şekilde, belki de sembolik bir anlam taşıması sebebiyle özellikle mihrap nişlerinde uygulanmıştır. Bunda, Avrupa'da gerçekleşen Rokoko ve Ampir gibi akımların etkisi olabilir, çünkü bu üsluplarda perde mekân dekorasyonunda, ortamın etkisini arttırmak amacıyla bir mefruşat olarak yoğun bir şekilde kullanılmış ve bu, doğal olarak Batı'dan etkilenen Osmanlı mimarisine yansımıştır. Ancak motifin tamamen Batı kaynaklı olduğu vurgusu yanlıştır.

Kompozisyonları oluşturan bezeme unsurlarından da anlaşılacağı üzere, Osmanlı İmparatorluğu, Orta Asya'dan Anadolu'ya uzanan Türk kültüründe yer alan motifleri kendi beğenileriyle sentezleyerek kullanmıştır. Örneğin bitkisel süslemeler arasında stilize edilerek uygulanan hayvan figürleri Hun ve Göktürk dönemlerine tarihlendirilen buluntularda, Anadolu Selçuklu devrinde İlhanlı etkisiyle ortaya konan yapılarda, Akkoyunluların "Vak Vak Üslubunda", Osmanlı'nın "Saz Yolu" olarak adlandırılan klasik dönem tezhibinde, perde ise Uygur dönemi ile başlayıp Osmanlı klasik devrinin sonuna kadar ortaya konmuş eserlerde kullanılmıştır.

Kısacası, Türklerin tarih sahnesine çıkışlarını takiben ortaya konan her türlü eser üzerine işlenen perde motifi, Türkler tarafından, dekorasyon ve tezyinat unsuru olarak erken devirlerden itibaren değerlendirilmiştir. Bu durum, Türk sanatında kullanılan rumi, hatayi gibi motiflerin yanı sıra perdenin de kaynağının kendi köklerinde olduğunu ve bu membadan beslenerek, gelişimini sürdürdüğünü ortaya koymaktadır.

\section{SUMMARY}

This study aims to reveal that the curtain which is said to take place in Turkish decorative arts by the effect of Western art has indeed been used in Turkish art since the Huns era and originated by Middle Asian Turks to the accompaniment of examples on the elements such as frescos, ceramics, miniatures, drawings and architecture.

SEFAD, 2021; (45): 271-294 
It is possible to observe by the extant examples that every kind of artwork has been decorated by elements under the headlines of floral, geometrical, figured, calligraphy, architectural images, objects or scenic decorations since the early periods of Turkish history. As well as the existing several studies on rumi, hatai and figured decorations, some motifs which find place among Turkish decorative arts since the early periods have hardly ever been mentioned or been approached superficially within the emphasis of a Western origin. One of these motifs which got its share from the mentioned point is curtain.

The first study mentioning that the curtain motif is of Western origin is a book titled "Batılılaşma Dönemi Türk Resim Sanatı 1700-1850". It is mentioned in the book that the curtain motif observed on the miniature in the manuscript titled Silsilename which depicts Selim I, is illustrated with the inspiration of European artists' paintings. In another study titled "Osmanlı Minyatürü", it is emphasized on the basis of the same miniature that the curtain motif depicted shady behind the sultans was stem from the European painting. Another work suggesting that the motif takes place in Turkish decorative arts by the Western effect is a book titled "Batılılaşma Dönemi Anadolu Tasvir Sanatı". It is mentioned in the study that along with the flowers in vases and garlands, curtains are also among the motifs of Western nature. Besides, on an unpublished doctoral dissertation titled "18. ve 19. Yüzyıllarda Osmanlı Duvar Resimlerinde Betimleme Anlayışı" the iconography of curtain motif is entreated while it is noted, based upon the previous studies, that the motif is of Western origin and have been used on miniatures earlier than mural paintings. Above mentioned sources have been the basis of several studies on Ottoman decorative arts but fails to go beyond the emphasis that curtain motif is of Western origin.

Turks have settled in tents named as yurt or domiciles named as bark and have attached great importance to their decoration. As well as climatic protection, the tendency of adding an aesthetical sight to the residential area have accommodated the utilization of furnishing elements such as carpets, rugs, coverings, mattresses and curtains. Among the mentioned elements, it is obvious that the curtains have a significant role; their use is not limited with covering the windows and they have been used by hanging on the exterior walls of the buildings, above beds, above or behind the emperor thrones and providing a wealthy sight and divinity to the place. By the passing time, curtain has gone beyond being an object of daily life and has been used as a decorative element for mural paintings, ceramics, miniatures, oil paintings, gravures and architecture.

Curtain motif, of which earliest depictions are observed in Uygur era, has generally been used on mural paintings; specifically, at the throne hall or on both sides of the prince or princess figures. The same tradition has been sustained in Iran and Anatolian Seljuks, walls of some palace buildings have been enlivened with curtain motifs in fresco technique and have been treated on miniatures in manuscript works. In decorative arts of Ottoman era, the Uygur tradition have been synthesized and utilized with Ottoman taste and relief technique curtain motifs have taken place particularly on the decoration of structural facades. Besides, on miniatures on which the Ottoman sovereign life, peculiarly sultan depictions and palace units were treated, and on the scenic depiction engravings, the curtain motif has been used in order to bring in a depth to the scene.

Probably because of its symbolic value, curtain motif is utilized particularly on prayer niches on late period works of art. It is possible to think that Rococo style of Europe has an effect for the fact that curtain has been used in this style as a furnishing element in the living 
space in order to enhance the ambiance; therefore, it has naturally been also used in Ottoman works which is affected by the West. However, the emphasis that the motif is of Western origin is misleading. The main motifs of baroque and imperial style which has taken effect on $18^{\text {th }}$ and $19^{\text {th }}$ century Ottoman decorative arts consist of flowers in the vases, fruits in the baskets, garlands, acanthus leaves, S-C curves, oyster shell forms, helmets, axes, weapons, flags, drums and masks. While the curtain has not been engraved as a motif on any kind of materials, it is possible to suggest that it is used in the decoration in order to enhance the living space.

As can be understood by the elements generating decorative compositions, the motifs of Turkish culture from Middle Asia to Asia Minor have been used by synthesizing their own taste in the Ottoman Empire. To exemplify, stylized animal figures among floral decorations have been used on finds dated to Hun and Gokturk periods, on works of Anatolian Seljuk period by the Ilkhanid effect, on the "Waqwaq Style" of Aq Qoyunlu State, on classical period illumination art named as "Saz Style" and curtain motifs have been used on works of arts starting from the Uygur period until the end of Ottoman classical period.

To conclude, subsequent to the appearance of the Turks on the scene of history, curtain motif engraved on any kind of work of art has been used by Turks as a decorative element from the early periods. In that case, it is revealed that origins of many motifs such as rumi, palmet, hatai, curtain, used in Turkish art lie at its own roots and have been sustaining their developments by feeding from that spring.

Makale Bilgileri

\begin{tabular}{ll}
\hline Etik Kurul Kararı: & Etik Kurul Kararından muaftır. \\
Katılımcı Rızası: & Katılımcı Yok \\
Mali Destek: & Çalışma için herhangi bir kurum ve projeden mali destek \\
& alınmamıştır. \\
Çıkar Çatışması: & $\begin{array}{l}\text { Çalışmada kişiler ve kurumlar arası çıar çatı̧̧ması } \\
\text { bulunmamaktadır. } \\
\text { Çalışmada kullanılan görsellerle ilgili telif hakkı } \\
\text { Telif Hakları: }\end{array}$ \\
sahiplerinden gerekli izinler alınmıştır.
\end{tabular}

Ethics Committee Approval: Informed Consent:

Exempt from the Ethics Committee Decision.

Financial Support: No participant

Conflict of Interest:

No financial support from any institution or project.

Copyrights:

No conflict of interest.

The required permissions have been obtained from the copyright holders for the images and photos used in the study. 


\section{KAYNAKÇA}

Aksu, H. (1981). III. Murad Şehinşahnamesi. Sanat Tarihi Yıllığı (S. IX-X, s. 1-22). İstanbul: İstanbul Üniversitesi Edebiyat Fakültesi Yayınları.

And, M. (2017). Osmanlı tasvir sanatları: minyatür 1, (2. bm.) İstanbul: YKY.

Arık, R. (1988). Batılılaşma dönemi Anadolu tasvir sanatı. (2. bs.). Ankara: Kültür ve Turizm Bakanlığı Yayınları.

Arık, R. (2017). Selçuklu saray ve köşkleri. (1. bs.). Ankara: Ankara Üniversitesi Yayınevi

Arslan, N. (1997). Mihri Müşfik. Eczacıbaşı Sanat Ansiklopedisi, (Cilt 2, s. 1244). İstanbul: Yem Yayınları.

Aslanapa, O. (1986). Osmanlı devri mimarisi, (2. bs.). İstanbul: İnkılap Kitapevi.

Aslanapa, O. (2011). Türk sanatı, 10. Baskı, İstanbul: Remzi Kitapevi.

Atasoy, N. (1992). Barok, İslam ansiklopedisi, (Cilt 5, s. 81-83). İstanbul: Türkiye Diyanet Vakfı Yayınları.

Bağcı, S. Çağman, F. Renda, G., Tanındı, Z. (2012). Osmanlı resim sanatı. (2. bs.). Ankara: T.C. Kültür ve Turizm Bakanlığı Yayınları.

Binan, C. (1997). Pencere. Eczacıbaşı sanat ansiklopedisi, (Cilt 3, s. 1443). İstanbul: Yem Yayınları.

Cezar, M. (1977). Anadolu öncesi Türklerde şehir ve mimarlkk. (1. bs.). İstanbul: İş Bankası Kültür Yayınları.

Çoruhlu, T. ve Alkan, M. (2017). Sakarya ili geleneksel Türk mimarisinde duvar resimleri ve boyalı nakışlar. XX. Uluslararası Ortaçă̆ ve Türk Dönemi Kazıları ve Sanat Tarihi Araştırmaları Sempozyumu Bildirileri (02-05 Kasım 2016), (Cilt 2, s. 898, 908) Ed. Ela Taş, Sakarya: Sakarya Üniversitesi Yayınları.

Çoruhlu, Y. (2013). Erken devir türk sanatı. (1. bs.). İstanbul: Kabalcı Yayınları

Devellioğlu, F. (2010). Osmanlıca Türkçe ansiklopedik lügat. Ankara: Aydın Kitabevi.

Doğanay, A. (2012). Tezyinat. İslam ansiklopedisi, (Cilt 41 s. 79, 83). İstanbul: Türkiye Diyanet Vakfı Yayınları.

Duran, T. (1999). Padişah Portreleri. (1. bs.). İstanbul: Tarihi Araştırmalar Vakfı Yayınları.

Erişim adresi: http://www.antikalar.com/iznik-seramikleri

Erişim adresi: https://tr.pinterest.com/pin/490610953128581164_.

Ertuğ, Z. T. (1998). Hünernâme. İslam ansiklopedisi, (Cilt 18, s. 484-485). İstanbul: Türkiye Diyanet Vakfı Yayınları.

Esin, E. (1975). Sadullah Paşa yalısının bağlı olduğu gelenek. Türkiyemiz (Sayı 16, s. 2, 7) İstanbul: Akbank Yayınları.

Esin, E. (2006). Türklerde maddi kültürün oluşumu. (1. bs.). İstanbul: Kabalcı Yayınları.

Germaner, S. (1997). Ampir. Eczacıbaşı sanat ansiklopedisi, (Cilt 1, s. 88). İstanbul: Yem Yayınları.

Giray, K. (2009). Ziraat Bankası Koleksiyonu. Ankara: Ziraat Bankası Sanat Koleksiyonu Yayınları.

Gürsoy, E (2015). Uşak'ta perde motifli mihraplar, ASOS JOURNAL Akademik Sosyal Araştırmalar Dergisi (Sayı 10, s. 146-157). Erişim adresi: 
http://isamveri.org/pdfdrg/G00028/2015_10/2015_10_GURSOYE.pdf (Erişim tarihi: 06.04.2019).

İnal, G. (1995). Türk minyatür sanatı (Başlangıcından Osmanlılara Kadar). (1. bs.). Ankara: Atatürk Kültür Merkezi Yayınları

İndirkaş, Z. (2002). Türklerde hükümdar tacı geleneği. (1. bs.). Ankara: Kültür Bakanlığı Yayınları.

Kuban, D. (2016). Osmanlı mimarisi. 2. Baskı, İstanbul: Yem Yayınları

Kuban, D. (2018). Türk ahşap konut mimarisi (17. - 19. Yüzyıllar). (3. bs.). İstanbul: İş Bankası Kültür Yayınları.

Kuran, A. (1997). Osmanlı mimarlığı ve sanatı. Eczacıbaşı Sanat Ansiklopedisi, (Cilt 3, s. 13931399). İstanbul: Yem Yayınları.

Küçük, C. (1988). Abdülmecid. İslam ansiklopedisi, (Cilt 1, s. 259-263). İstanbul: Türkiye Diyanet Vakfı Yayınları.

Merçil, E. (1996). Gazneliler. İslam ansiklopedisi, (Cilt 13, s. 480, 483). İstanbul: Türkiye Diyanet Vakfı Yayınları.

Merçil, E. (2000). Türkiye Selçuklularında Meslekler. (1. bs.) Ankara: TTK Yayınları

Okçuoğlu, T. (2000). 18. - 19. yüzyıllarda Osmanlı duvar resimlerinde betimleme anlayışı, Yayımlanmamış doktora tezi. İstanbul: İstanbul Üniversitesi, Sosyal Bilimler Enstitüsü Sanat Tarihi Anabilim Dalı.

Ögel, B. (1978a). Türk kültür tarihine giriş I (Türklerde köy ve şehir hayatı). (1. bs.). Ankara: Kültür Bakanlığı Yayınları.

Ögel, B. (1978b). Türk kültür tarihine giriş III (Türklerde ev kültürü). (1. bs.) Ankara: Kültür Bakanlığı Yayınları.

Özcan, A. (2004). Merzifonlu Kara Mustafa Paşa. İslam ansiklopedisi, (Cilt 29, s. 246, 249). Ankara: Türkiye Diyanet Vakfı Yayınları.

Özgüdenli, O. G. (2009). Büyük Selçuklularda sosyo-ekonomik ve kültürel hayat. İslam ansiklopedisi, (Cilt 36, s. 371, 375). İstanbul: Türkiye Diyanet Vakfı Yayınları.

Özünlü, E. E. (2014). Osmanlı ve Kırgız konargöçerlerinde yurt, bilig, Türk dünyası sosyal bilimler dergisi, (Sayı 71, s. 169-178). Erişim adresi: https://dergipark.org.tr/tr/download/article-file/233594 (Erişim tarihi:05.07.2019)

Pancaroğlu, O. (2015). Resimli ve tasvirli el yazmaları. Anadolu Selçukluları ve Beylikler dönemi uygarlığı 2, 1. Baskı, Ankara: Kültür ve Turizm Bakanlığı Yayınları, s. 575-586.

Renda, G. (1977). Batılılaşma dönemi Türk resim sanatı 1700-1850 (1. bs.), Ankara: Hacettepe Üniversitesi Yayınları.

Renda, G. (1997). Osmanlı Minyatürü. Eczacıbaşı sanat ansiklopedisi, (Cilt 2, s. 1270). İstanbul: Yem Yayınları.

Sevim, A. ve Merçil, E. (1995). Selçuklu Devletleri Tarihi (6. bs.), Ankara: TTK Yayınları.

Seyran, E. (2005). Mihri Müş̧ik (Yaşamı ve sanatı). Yayımlanmamış yüksek lisans tezi, İstanbul: Marmara Üniversitesi, Türkiyat Araştırmaları Enstitüsü, Türk Sanatı Anabilim Dalı.

Sümer, F. (2009a). Anadolu Selçukluları. İslam ansiklopedisi, (Cilt 36, s. 380-384). İstanbul: Türkiye Diyanet Vakfı Yayınları.

SEFAD, 2021; (45): 271-294 
Sümer, F. (2009b). Büyük Selçuklular. İslam ansiklopedisi, (Cilt 36, s. 365-371). İstanbul: Türkiye Diyanet Vakfı Yayınları.

Taşağıll, A. (2012). Türk. İslam ansiklopedisi, (Cilt 41, s. 467-474). İstanbul: Türkiye Diyanet Vakfı Yayınları.

Toros, T. (1988). Illk kadın ressamlarmmz. (1. bs). İstanbul: Ak Yayınları.

Yurtsal, T. (2009). Aydın ve Denizli camilerinde duvar yapıları. Yayımlanmamış yüksek lisans tezi. Ankara: Gazi Üniversitesi, Sosyal Bilimler Enstitüsü, Sanat Tarihi Anabilim Dalı. 